Article

\title{
Understanding the Evolution of Industrial Symbiosis with a System Dynamics Model: A Case Study of Hai Hua Industrial Symbiosis, China
}

\author{
Hua Cui ${ }^{1}$, Changhao Liu ${ }^{1, *}$, Raymond Côté ${ }^{2}$ and Weifeng Liu ${ }^{3}$ \\ 1 School of Chemistry and Chemical Engineering, Beijing Institute of Technology, Beijing 100081, China; \\ cuihua0416@126.com \\ 2 School for Resource and Environmental Studies, Dalhousie University, Halifax, NS B3H 4R2, Canada; \\ raymond.cote@dal.ca \\ 3 School of Life Science, Beijing Institute of Technology, Beijing 100081, China; breeze@bit.edu.cn \\ * Correspondence: changhao.liu@hotmail.com; Tel.: +86-10-8138-1383
}

Received: 22 August 2018; Accepted: 23 October 2018; Published: 25 October 2018

\begin{abstract}
Industrial symbiosis (IS) is a key sub-field in industrial ecology. The field itself assists in developing strategies that support local and regional sustainable development. The evolution of IS is an important topic to be explored. In this paper, we use the system dynamics (SD) method to establish a model of the evolution of industrial symbiosis in the case of Hai Hua Industrial Symbiosis (HHIS). In this model, different scenarios for energy consumption, solid waste utilization, and wastewater utilization were set by changing the parameter values of certain input variables to analyze the evolution of HHIS. In addition, the drivers for IS evolution were investigated qualitatively in this study. The SD model was helpful for visualizing the effects and benefits of reducing the energy consumption, solid waste stock, and wastewater stock that were achieved by establishing symbiotic relationships during the evolution of IS. The results show that the optimization of energy and material flows and other symbiotic benefits can be achieved in HHIS. There are still some challenges that restrict the further evolution of HHIS. Some suggestions are proposed to promote its further evolution.
\end{abstract}

Keywords: industrial ecology; industrial symbiosis; system dynamics; evolution; drivers

\section{Introduction}

Industrial ecology (IE) is a creative theory aiming at realizing a coordinated development between industry and environment [1]. Industrial symbiosis (IS) is a key sub-field of IE [2,3]. Both economic and environmental performance can often be achieved through IS [4], which in turn contributes to local and regional sustainable development $[5,6]$. Chertow [7] defined IS as "engaging traditionally separate entities in a collective approach to competitive advantage involving [the] physical exchange of materials, energy, water, and by-products. The keys to IS are collaboration and the synergistic possibilities offered by geographic proximity" [7] (p. 314). Based on this definition, crossing academicpractitioner boundaries, Lombardi and Laybourn [8] redefined IS as engaging "diverse organizations in a network to foster eco-innovation and long-term culture change. Creating and sharing knowledge through the network yields mutually profitable transactions for the novel sourcing of required inputs, value-added destinations for non-product outputs, and improved business and technical processes" [8] (pp. 31-32). The evolution of IS is considered an important topic to be explored, which is helpful for understanding the dynamic process of IS and future planning [9-11]. The industrial ecosystem is a well-recognized concept associated with IS [12]. Jelinski et al. [13] argued that an industrial ecosystem is a system that evolves over time. IS should be seen as a dynamic process rather than a fixed state where a series of changes involving agents, resource flows, and economic and ecological 
impacts could occur [9,14-19]. For example, the famous industrial symbiosis of Kalundborg, Denmark, has evolved over a period of more than 40 years [20,21]. Understanding the evolution of IS could be helpful for implementing the development of IS projects $[7,10]$. Furthermore, it has contributed to shifting a traditional industrial park to an eco-industrial park, and is helpful for the planning and construction of eco-industrial parks [22,23]. Although the evolution of IS has been identified as an important topic in the IE field, most of the studies have been qualitative in nature. The system dynamics (SD) method, which serves as a modeling and simulation tool specifically designed for long-term, dynamic problems [24], helps us visualize the effects of different strategies through simulation [25].

Taking Hai Hua Industrial Symbiosis (HHIS) as a case study, this paper aims to uncover the evolutionary trajectory of IS using an SD model, which can connect the fields of IS and SD. The drivers for the evolution of HHIS are integrated into the study for analyzing how HHIS evolves under the impact of these drivers.

This paper is structured as follows. Section 2 provides a literature review covering the evolution of IS as well as the drivers for IS evolution. Section 3 describes the research methods. Section 4 describes a SD model to uncover the evolutionary trajectory of IS using HHIS as a case study. Finally, some conclusions are drawn in Section 5.

\section{Literature Review}

\subsection{Evolution of IS}

The research related to the evolution of IS can be mainly divided into three aspects: (1) the stages of IS evolution, (2) the characteristics of IS evolution, and (3) the research methods of IS evolution.

\subsubsection{Stages of IS Evolution}

Some researchers considered that IS evolution can be divided into several stages [9,11,13,16,26-28]. By emulating a natural ecosystem model, Jelinski et al. [13] argued that the evolutionary process of an industrial ecosystem includes three stages, i.e., type I, type II, and type III. Using the Uimaharju forest industry park of Finland as a case study, Korhonen and Snäkin [29] tested these stages, and found that they could be well-demonstrated in that case study. Chertow and Ehrenfeld [16] presented a discontinuous three-stage model, i.e., sprouting, uncovering, and embedding and institutionalizing, to examine the generation and development of IS. They found that industrial symbiotic networks could follow different development paths, but would eventually evolve toward a more sustainable direction. Based on three IS cases, i.e., Kalundborg, the National Industrial Symbiosis Programme (NISP) and Sagunto, Doménech and Davies [26] identified three phases of IS evolution including emergence, probation, and development and expansion, and analyzed the role of trust and embeddedness in these different phases. Paquin and Howard-Grenville [11] examined the evolution of a facilitated IS network, i.e., the United Kingdom (UK)'s NISP. They found that the IS evolution process is composed of identifying potential and preexisting firms, deepening the cooperation among firms while introducing relevant firms, and expanding symbiotic exchanges, with goal-directed progress being dominant. They labeled these three phases as "pre-network development", "earlier network development", and "later network development". Taking a Finnish forest industry complex as an example, Pakarinen et al. [27] investigated the IS evolution and divided the evolutionary process into three stages, i.e., linear materials and energy flows, the expansion of the system and increased diversity of actors forming several connections, and the increasing complexity of the system. The related evolutionary models are summarized in Table 1, but the basic elements are similar. 
Table 1. The evolution models of industrial symbiosis (IS).

\begin{tabular}{lc}
\hline \multicolumn{1}{c}{ Descriptions } & References \\
\hline Type I, type II, and type III, which emulates a natural ecosystem model & {$[13]$} \\
\hline Testing type I, type II, and type III & {$[9,29]$} \\
\hline $\begin{array}{l}\text { A discontinuous three-stage model including sprouting, uncovering, and embeddedness } \\
\text { and institutionalization }\end{array}$ & {$[16]$} \\
\hline $\begin{array}{l}\text { IS evolution process can be divided into three stages, i.e., linear materials and energy flows, } \\
\text { the expansion of the system and increased diversity of actors forming several connections, } \\
\text { and the increasing complexity of the system. }\end{array}$ & {$[27]$} \\
\hline $\begin{array}{l}\text { A middle-out approach creating a favorable context for fostering IS development } \\
\text { Three phases of IS evolution including emergence, probation, and development }\end{array}$ & {$[28]$} \\
and expansion & {$[26]$} \\
\hline $\begin{array}{l}\text { IS evolution process encompasses identifying potential and preexisting firms, deepening } \\
\text { the cooperation among firms while introducing relevant firms, and expanding symbiotic } \\
\text { exchanges, with goal-directed progress being dominant. }\end{array}$ & {$[11]$} \\
\hline
\end{tabular}

\subsubsection{Characteristics of IS Evolution}

Many researchers have recognized that IS should be seen as a dynamic process [15-20]. Jacobsen [21] argued that the evolution of IS can be considered as a process of resource optimization. This was reflected in Jelinski's three-stage model [13]. Others argued that the evolution of IS was not just an optimized process of material flows; instead, it migrated toward a more complex system, in which the number of decomposer companies and IS chains gradually increased $[7,9,29,30]$. Korhonen and Snäkin [29] introduced two principles of an ecosystem, i.e., "roundput" and "diversity", into the study of the evolution of a forest industry park. Roundput refers to cyclical materials and cascading energy flows that could lead to resource optimization. Diversity refers to the different participants, resources, and technologies. They found that both "roundput" and "diversity" are important characteristics for exploring the evolution of an industrial ecosystem. In another paper, Korhonen and Snäkin [9] found that during the evolutionary process, the number of companies and symbiotic chains increased, the production capacity and technology significantly improved, and the geographical boundary of the system expanded. Cao et al. [31] concluded that in the evolutionary process of eco-industrial systems, product categories and industrial chains increased, and the system sustainability became much higher. Huo et al. [19] pointed out that eco-industrial systems became gradually more stable as time progressed. Shi and Chertow [32] examined the case of the Guitang Group and found that the number and diversity of IS companies, and thus the internal and external symbioses, increased over time. They argued that the evolution of the Guitang Group IS can be characterized as organizational boundary change.

\subsubsection{Methods Used in Researching IS Evolution}

Several methods have been used in the research on IS evolution [19,30-33]. Taking Kalundborg IS as an example, Huo et al. [19] adopted physical principles and simulations to study the structural evolution of this industrial ecosystem. Baldwin and Ridgway [30] presented four model assumptions related to the problem of evolution of IE, i.e., equilibrium models, non-linear system dynamics models, self-organizing dynamic models, and evolutionary models, which could serve as a decision support tool for future study and implementation of IS. Cao et al. [31] applied an agent-based model to analyze the evolution of eco-industrial systems based on a case study of an eco-industrial park in Sichuan Province of China. Shi and Chertow [32] used material flow analysis (MFA) and social network analysis (SNA) to uncover the evolution of Guitang Group IS. Felicio et al. [33] introduced the concept of "environment impact momentum" and IS indicators to describe the evolution of IS. Ashton et al. [34] developed a five-node model to examine the evolution of self-organized industrial ecosystems. 


\subsection{Drivers for IS Evolution}

The evolutionary process of IS is driven by a variety of factors, which act as dynamics for the evolution of IS. Identifying the drivers for IS evolution could be helpful for promoting the IS to achieve efficient and rapid development. The drivers of IS evolution can be mainly classified into six categories, i.e., resource, government, economy, company, technology, and society, which are shown in Table 2.

Table 2. Drivers of the evolution of IS. IE: industrial ecology.

\begin{tabular}{|c|c|c|c|}
\hline Category & Drivers & Explanation & References \\
\hline \multirow{2}{*}{ Resource } & Resource scarcity & $\begin{array}{l}\text { Resource scarcity can lead to the reuse of water and materials, } \\
\text { which is helpful for the establishment and development of IS. }\end{array}$ & {$[20,35,36]$} \\
\hline & $\begin{array}{l}\text { Availability of } \\
\text { wastes }\end{array}$ & $\begin{array}{l}\text { Availability of wastes can drive one company to locate itself } \\
\text { near other companies, generating the wastes it required. }\end{array}$ & [37] \\
\hline \multirow[b]{2}{*}{ Government } & $\begin{array}{l}\text { Regulations and } \\
\text { standards }\end{array}$ & $\begin{array}{l}\text { Strict environmental regulations and standards issued by the } \\
\text { government can create a favorable context for IS emergence } \\
\text { and stimulate companies to reuse waste. }\end{array}$ & {$[20,22,28,38-41]$} \\
\hline & Financial support & $\begin{array}{l}\text { Financial support provided by the government such as tax } \\
\text { cuts, refund policies, price support, and public subsidies, is } \\
\text { conducive to catalyze companies to comprehensive resource } \\
\text { utilization and waste reuse. }\end{array}$ & {$[40,42-45]$} \\
\hline \multirow{3}{*}{ Economy } & Economic benefit & $\begin{array}{l}\text { Economic benefits achieved from by-product utilization, } \\
\text { transportation cost-saving, and raw material substitution are } \\
\text { strong incentives for companies to search for IS possibilities. }\end{array}$ & {$[10,22,27,40,41,46,47]$} \\
\hline & Financial payback & $\begin{array}{l}\text { Short financial payback time makes it possible for companies } \\
\text { to invest in new equipment for establishing IS relationships. }\end{array}$ & {$[48,49]$} \\
\hline & $\begin{array}{l}\text { New business } \\
\text { opportunities }\end{array}$ & $\begin{array}{l}\text { New products can be produced through establishing IS } \\
\text { relationships, leading to the creation of new business } \\
\text { opportunities. }\end{array}$ & {$[50,51]$} \\
\hline \multirow{4}{*}{ Company } & $\begin{array}{l}\text { Short mental } \\
\text { distance }\end{array}$ & $\begin{array}{l}\text { Short mental distance could overcome barriers connected to } \\
\text { collaboration and notional correlation, which is conducive to } \\
\text { reach a consensus, share information, and establish IS. }\end{array}$ & {$[20,52]$} \\
\hline & Trust & $\begin{array}{l}\text { Trust is helpful for companies to reduce transaction risk, } \\
\text { reduce access barriers, share production information, } \\
\text { and promote the willingness of establishing IS. }\end{array}$ & {$[26,47,53-58]$} \\
\hline & Security & $\begin{array}{l}\text { Cluster safety, supply security assurance, the safe disposal of } \\
\text { waste, and risk management realized by waste reuse } \\
\text { stimulates the establishment of IS. }\end{array}$ & {$[20,59,60]$} \\
\hline & Awareness & $\begin{array}{l}\text { A high level of environmental awareness, the awareness of } \\
\text { waste and by-products that are available to be utilized, } \\
\text { and the understanding of the IE concept could motivate } \\
\text { companies to seek possible opportunities of waste exchange } \\
\text { and recycling. }\end{array}$ & {$[24,49,53]$} \\
\hline Technology & $\begin{array}{l}\text { Technology } \\
\text { innovation }\end{array}$ & $\begin{array}{l}\text { Environmental technology, emerging technology innovation, } \\
\text { and the improvement of technology provide companies with } \\
\text { solutions for waste reuse. }\end{array}$ & {$[22,27,29,59]$} \\
\hline Society & $\begin{array}{l}\text { Social organization } \\
\text { or support system }\end{array}$ & $\begin{array}{l}\text { Existence of a social organization or support system can help } \\
\text { companies seek opportunities for IS, such as trade } \\
\text { associations and shared services. }\end{array}$ & {$[20,53]$} \\
\hline
\end{tabular}

From this literature review, it can be seen that although the evolution of IS has been considered as an important topic in the IE field, most of the studies have been qualitative in nature. There is a gap in the studies of the evolution of IS involving the SD method. Therefore, by introducing a SD model on IS evolution and combining the drivers of IS evolution into this study, this paper could fill this gap.

\section{Methodology}

System dynamics (SD), developed by Forrester [61], is a method combining quantitative and qualitative analysis based on the feedback control theory and computer simulation technology, 
which has been used in various fields [61,62]. SD is considered an effective tool for dealing with non-linear and dynamic complexity problems $[63,64]$. The purpose of SD research is to understand how and why the dynamic changes are generated, and search for relevant policies to improve system performance [64,65]. The SD model can be regarded as a laboratory of an actual system that can clearly present the interrelationships among the internal variables of a system $[61,66]$. This paper introduces SD to establish a model of the evolution of IS based on the case study of HHIS. The SD model can be used to quantify the evolutionary path and characteristics of IS. Moreover, the drivers are used in the paper to qualitatively analyze the roles that the drivers played during the evolution of HHIS.

To collect the information and data needed for this paper, field research at both the company and local government levels was conducted. At the company level, open-ended interviews with the managers and technicians of the Hai Hua Group (HHG) and symbiotic companies were conducted. These are the soda plant, the thermal power plant, the bromine plant, the calcium chloride plant, the potassium sulfate plant, the saleratus plant, and the chlor-alkali colophony plant. In each company, we interviewed senior managers and other managers who are responsible for planning, technology, finance, security, and environmental protection. Then, through the interviews, we obtained detailed information about the evolution of Hai Hua Industrial Symbiosis (HHIS), including the timing and rationale for the establishment or disappearance companies and symbiotic relationships, the main material and energy flows, the drivers for HHIS, the business development plans, and the main challenges for HHIS. Meanwhile, the data needed for SD modeling was collected, including the product output, solid waste generation rate, wastewater generation rate, wastewater utilization rate, and economic benefits from establishing IS. At the local government level, we conducted open-ended interviews with the government staff from the local environmental protection bureau, which is the management department in charge of the National Eco-industrial Demonstration Park. The interviewees were the director of the environmental protection bureau, people who were responsible for managing the local eco-industrial park, and other people who were familiar with the local eco-industrial park development. Thus, we could gather information on the socio-political background of the development of HHIS and the role that the government played in the evolution of HHIS. In addition, data was also gathered from reports of HHG, government documents, the literature, and relevant websites.

\section{Case Study of HHIS}

\subsection{Background Information}

HHIS is located in the Weifang Binhai Economic and Technological Development Zone (WBETDZ) in Shandong Province, China. The main participants of HHIS are attached to HHG. HHIS was developed based on the salt-soda operations of the Yangkou salt field and Weifang soda plant in 1995. Other symbiotic companies were introduced later [67]. Evolving over 20 years, HHIS gradually formed a characteristic marine chemical industrial symbiosis, which focuses on underground brine and seawater utilization. At present, the key participating companies are a salt field, a soda plant, a thermal power plant, a bromine plant, a saleratus plant, a potassium sulfate plant, a calcium chloride plant, a petrochemical company, and a chlor-alkali colophony plant. The major products are salt, soda, bromine, potassium sulfate, calcium chloride, bromide, and chlor-alkali. In 2005, WBETDZ, in which HHIS is located, was designated as a National Eco-industrial Demonstration Park by the State Environmental Protection Administration (SEPA, now the Ministry of Ecology and Environment, $\mathrm{MEE}$ ), and is currently the only national-level marine chemical eco-industrial park in China. In the same year, HHG, the parent company of HHIS, was identified as one of the National Circular Economy Pilot Enterprises by the National Development and Reform Commission (NDRC). The symbiotic relationships in HHIS are shown in Figure 1 and Table 3. 


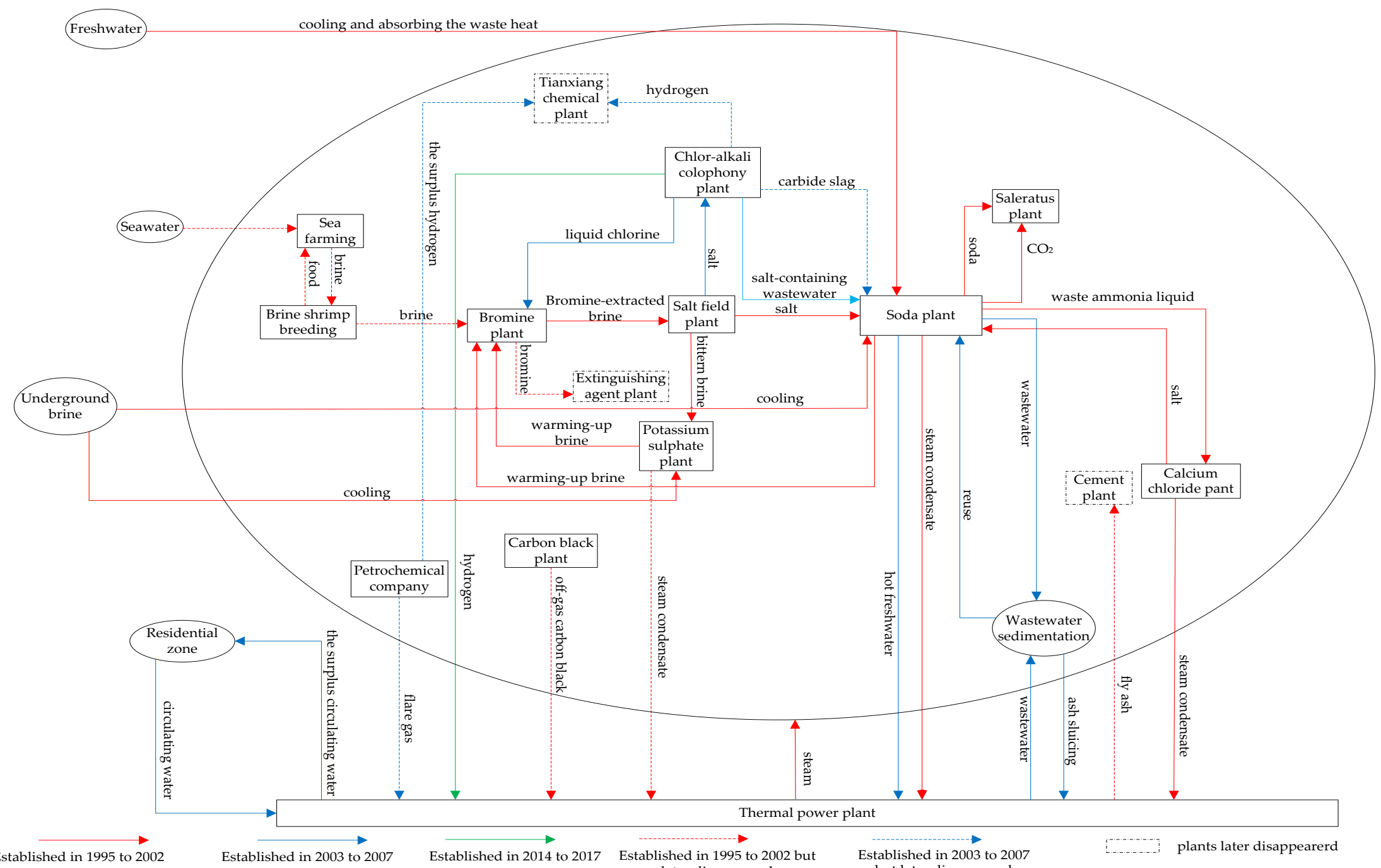

Established in 1995 to $2002 \quad$ Established in 2003 to $2007 \quad$ Established in 2014 to $2017 \quad$ Established in 1995 to 2002 but $\quad$ Established in 2003 to 2007

Figure 1. The industrial symbiotic relationships in Hai Hua Industrial Symbiosis (HHIS). 
Table 3. The utilization of main types of wastes through establishing symbiotic relationships during the evolution process of HHIS.

\begin{tabular}{|c|c|c|c|}
\hline Category & Specific Content & Descriptions of Symbiotic Relationships & Dates of Establishment \\
\hline \multirow{5}{*}{ Energy } & \multirow[t]{2}{*}{ Waste heat } & $\begin{array}{l}\text { The brine is first piped to the soda plant as part of the process } \\
\text { cooling water to absorb the waste heat. Then, the warmed } \\
\text { brine is piped to the bromine plant, which promotes the } \\
\text { bromine extraction percentage. }\end{array}$ & 1995 \\
\hline & & $\begin{array}{l}\text { The freshwater is first piped to the soda plant as cooling water } \\
\text { to absorb the waste heat. Then, the warmed freshwater is } \\
\text { returned to the thermal power plant for chemical treatment. }\end{array}$ & 1995 \\
\hline & \multirow{3}{*}{$\begin{array}{l}\text { Combustible exhaust gas } \\
\text { (off-gas carbon black, } \\
\text { flare gas, and hydrogen) }\end{array}$} & $\begin{array}{l}\text { The off-gas from the carbon black plant is piped to the thermal } \\
\text { power plant for combustion. }\end{array}$ & $\begin{array}{c}2008 \\
\text { (disappeared in 2015) }\end{array}$ \\
\hline & & $\begin{array}{l}\text { The flare gas from the petrochemical company is piped to the } \\
\text { thermal power plant for combustion. }\end{array}$ & 2008 \\
\hline & & $\begin{array}{l}\text { The hydrogen from the chlor-alkali colophony plant is piped } \\
\text { to the thermal power plant for combustion. }\end{array}$ & 2012 \\
\hline \multirow{3}{*}{ Solid waste } & Fly ash & $\begin{array}{l}\text { The fly ash from the thermal power plant is transported to the } \\
\text { cement plant as the raw material for producing cement. }\end{array}$ & $\begin{array}{c}1995 \\
\text { (disappeared in 2007) }\end{array}$ \\
\hline & Carbide slag & $\begin{array}{l}\text { The carbide slag from chlor-alkali colophony plant is piped to } \\
\text { soda plant as the raw material for producing soda. }\end{array}$ & $\begin{array}{c}2005 \\
\text { (disappeared in 2012) }\end{array}$ \\
\hline & Caustic sludge & $\begin{array}{l}\text { The caustic sludge from the soda plant has been stacked to the } \\
\text { residue field. There is still no symbiotic relationship related to } \\
\text { caustic sludge utilization. }\end{array}$ & 1995 \\
\hline \multirow{4}{*}{ Wastewater } & Waste ammonia liquid & $\begin{array}{l}\text { The waste ammonia liquid from the soda plant is firstly solar } \\
\text { evaporated, and then piped to the calcium chloride plant as } \\
\text { the raw material for producing calcium chloride. }\end{array}$ & 1997 \\
\hline & Bittern brine & $\begin{array}{l}\text { The bittern brine generated during the solar salt process in the } \\
\text { salt field is piped to the potassium sulfate plant as the raw } \\
\text { material for producing potassium sulfate. }\end{array}$ & 1995 \\
\hline & \multirow[t]{2}{*}{ Other wastewater } & $\begin{array}{l}\text { The wastewater from the soda plant and thermal power plant } \\
\text { is collected by a wastewater treatment facility shared by these } \\
\text { two companies, and then reused for ash-flushing, } \\
\text { salt-dissolving, and circulating water after being treated. }\end{array}$ & 1995 \\
\hline & & $\begin{array}{l}\text { The steam condensate is returned to the thermal power plant } \\
\text { for reuse. }\end{array}$ & 1995 \\
\hline
\end{tabular}

\subsection{SD Model of HHIS}

\subsubsection{Model Design}

This paper takes the utilization of energy, material, and water resources into account when uncovering the evolution of HHIS. Based on the characteristics of HHIS, the paper mainly focuses on the utilization of energy, solid waste, and wastewater utilization through establishing symbiotic relationships during the evolutionary process of HHIS. The specific contents are shown in Table 3. Vensim software is a commonly used SD model tool with advantages in visual and multiple windows interfaces [68]. It can help users easily and intuitively understand the SD model [69]. This paper adopted the software to draw a causal loop diagram and stock-flow diagrams and carry out numerical simulation. SD encompasses qualitative (conceptual) and quantitative (numerical) modeling [70]. Qualitative modeling is achieved by causal loop diagrams, aiming to improve our understanding of conceptual systems through explaining the key causal chains [25]. Quantitative modeling helps to visualize the effects of different scenarios through simulation using stock-flow models $[25,68]$. Both of them can be achieved by Vensim software.

Based on the above information, a causal loop diagram covering the basic aspects considered in the evolution of HHIS was drawn in Vensim (PLE version), and is shown in Figure 2. 


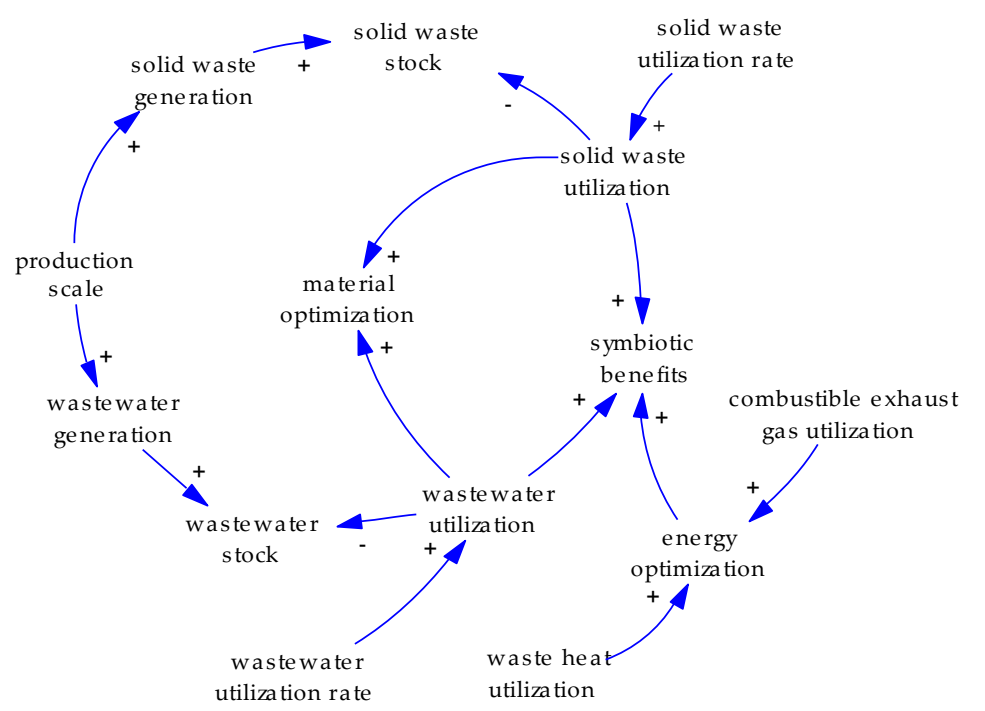

Figure 2. Causal loop diagram describing the basic evolution dynamics of HHIS.

The interaction between two variables can be described by causal chains indicated by arrows from "cause" to "effect". The polarity of cause chains (positive or negative) indicates how the dependent variable will change as the independent variable changes [71]. The positive polarity ("+") indicates a positive correlation. While similarly, the negative polarity ("-") indicates a negative correlation [63]. As shown in Figure 1, based on the actual situation of HHIS, if the production scale in HHIS expands, the generation of solid waste and wastewater will both increase. Then, the wastewater stock and solid waste stock will increase as well. If the utilization rate of wastewater and solid waste achieved by establishing symbiotic relationships increases, the quantity of the utilization of wastewater and solid wastes will increase, and the stock of wastewater and solid waste will decrease. Then, the optimization of materials will be improved, and the symbiotic benefits will also increase. There are types of combustible exhaust gas in HHIS, such as off-gas carbon black, flare gas, and hydrogen. If the utilization of combustible exhaust gas and the waste heat increase, the optimization of energy will be improved, and the economic benefits will increase as well.

The causal loop diagram can describe the basic relationships between variables related to the energy and materials in HHIS. A stock-flow diagram is a more detailed and in-depth description of a system structure, which can not only clearly reflect the logical relationships among variables, it also can further divide the variables into different sorts, including "level variable", "rate variable", "auxiliary variable", and "constant" [63,64]. Based on the causal loop diagram and the characteristics of HHIS, a stock-flow diagram was established, which is shown in Figure 3. Flow is composed of inflow and outflow, which are rate variables. For example, the output of waste ammonia liquid is the inflow, and the utilization of waste ammonia liquid is the outflow. The inflow minus outflow is the increment. The stock is the accumulation of the increment within a certain time (one year was chosen in this paper). The level variable refers to the change over time in the accumulation of the increment, such as the stock of solid waste and wastewater. The rate variable reflects the rate of inflow and outflow, and directly changes the accumulation of the increment, such as the annual solid waste increment and annual wastewater increment. The auxiliary variable is an exogenous or intermediate variable [68], such as the quantity of recycling of wastewater and bittern brine utilization. The constant refers to variables that can be considered to be constant over time, because of changing very slowly [68]. Shadow variables are printed between ' $\langle>$ ', which assists in drawing the stock-flow diagram. With these variables, a stock-flow model can be achieved using the Vensim software. 


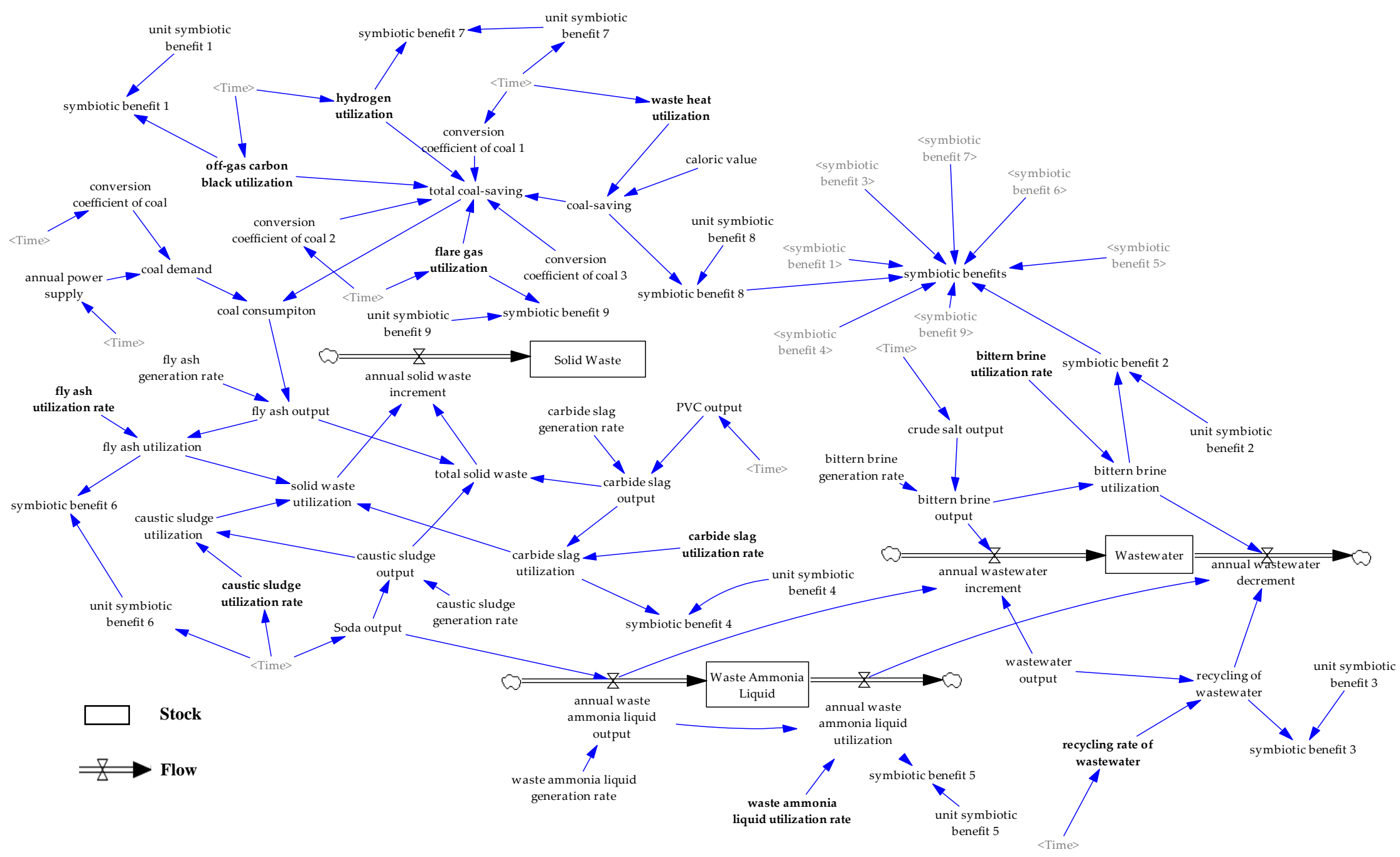

Figure 3. The stock-flow diagram of the evolution of HHIS. 
According to the field research at HHIS, the key symbiotic relationships of HHIS focus on coal, solid waste, and wastewater. Therefore, in the stock-flow diagram, the variable of coal consumption was used to characterize the energy utilization within HHIS. Two state variables, including solid waste stock and wastewater stock, were used to characterize the utilization of material during the evolution of HHIS.

\subsubsection{Model Analysis}

As mentioned, an SD model can simulate the different situations of a system under different scenarios [72]. Hence, this paper adopts the method of scenario analysis to uncover the evolution of HHIS. Through scenario analysis, the effect of input variables on the behavior changes of energy consumption, solid waste stock, wastewater stock, and symbiotic benefits in HHIS can be analyzed. For this reason, in the scenario analysis, we changed the parameter values of the input variables, such as waste heat utilization, fly ash utilization rate, and bittern brine utilization rate, which is helpful for uncovering the evolutionary path of HHIS. The table function in SD aims to describe the non-linear relationship between variables, which is achieved through function calls in the form of "WITH LOOKUP" in Vensim PLE. In HHIS, the utilization of waste heat, off-gas carbon black, flare gas, and hydrogen, and the recycling rate of wastewater change over time, but there are no linear relationships between these variables and time. Therefore, through the table function, the quantitative relationships between these variables and time can be expressed graphically. The table functions that are established in this paper are shown in Appendix A.

Based on the actual situation of HHIS, this paper considered the following scenarios related to energy consumption, solid waste, and wastewater. Energy consumption involved six scenarios. The current situation of energy consumption is the base scenario. Scenarios 1 to 4 refer to scenarios that assume no symbiotic relationships among the energy utilization of waste heat, off-gas carbon black, flare gas, and hydrogen, respectively. Scenario 5 assumes no symbiotic relationships of energy utilization exist in HHIS. Four scenarios were considered on solid waste. The practical situation of solid waste utilization is the base scenario (current scenario). Scenario 1 and scenario 2 assume the zero utilization rate of fly ash and carbide slag, respectively. Scenario 3 assumes that no symbiotic relationships regarding solid waste utilization exist in HHIS. Five scenarios were considered for wastewater. The practical situation of wastewater utilization is the base scenario (current scenario). Scenario 1 assumes a zero recycling rate of wastewater. Scenarios 2 and 3 assume zero utilization rates for waste ammonia liquid and bittern brine, respectively. Scenario 5 assumes that no symbiotic relationships regarding wastewater utilization exist in HHIS.

In addition, the evolution of HHIS is affected by various drivers. These drivers play a significant role in establishing symbiotic relationships within HHIS. The drivers that were investigated mainly involve the government, companies, the economy, technology, and resources. In this paper, the drivers were introduced to analyze the results of the model.

\subsection{Results and Discussion}

\subsubsection{Energy Consumption Analysis}

Coal is the main energy source in HHIS, which is mainly consumed by the thermal power plant. The thermal power plant is one of the core companies in HHIS. It adopts the technology of combined heat and power (CHP) production, and provides power and steam for other enterprises in HHIS. The coal consumption in the thermal power plant accounts for more than $75 \%$ of the total coal consumption within HHIS. Therefore, the path of energy optimization during the evolution of HHIS can be revealed by analyzing the coal consumption in the thermal power plant.

The scenario analysis of energy consumption is shown in Table 4. From the simulation of six scenarios, the results of energy consumption during the evolutionary process of HHIS is shown in Figure 4. 
Table 4. The scenario analysis of energy consumption in HHIS.

\begin{tabular}{ccccc}
\hline Scenario & $\begin{array}{c}\text { Waste Heat } \\
\text { Utilization }\end{array}$ & $\begin{array}{c}\text { Off-Gas Carbon } \\
\text { Black Utilization }\end{array}$ & $\begin{array}{c}\text { Flare Gas } \\
\text { Utilization }\end{array}$ & $\begin{array}{c}\text { Hydrogen } \\
\text { Utilization }\end{array}$ \\
\hline Current-curve 6 & table function ${ }^{1}$ & table function & table function & table function \\
Scenario 1-curve 1 & 0 & table function & table function & table function \\
Scenario 2-curve 2 & table function & table function & table function \\
Scenario 3-curve 3 & table function & table function & 0 & table function \\
Scenario 4-curve 4 & table function & table function & table function & 0 \\
Scenario 5-curve 5 & 0 & 0 & 0 & 0 \\
(No IS on energy utilization) & & & & 0 \\
\hline
\end{tabular}

${ }^{1}$ Table function can be seen in Appendix A.

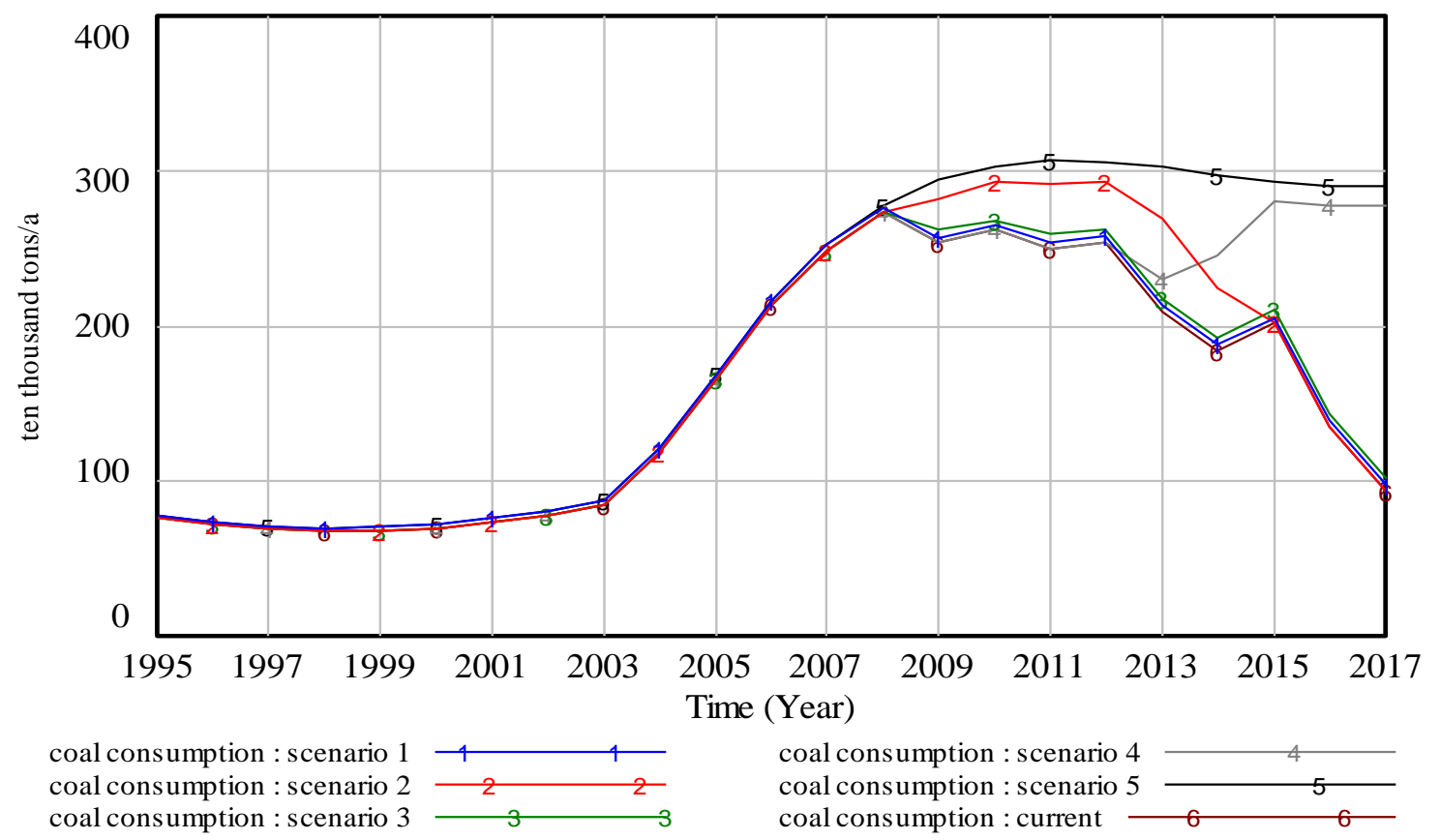

Figure 4. The trends of energy consumption in HHIS.

From 1995 to 2003, curves 1 to 6 are relatively flat, which indicates that the energy consumption in HHIS was relatively stable. During this stage, there is not much difference between these curves. The reason is that there were no symbiotic relationships on energy utilization other than waste heat utilization from 1995 to 2008, which makes curves 2 to 4 coincide with curve 6 . Curve 1 coincides with curve 5 from 1995 to 2008, because no symbiotic relationships existed during this stage under the two scenarios. Only curve 1 is above curve 5, which indicates that the energy consumption of HHIS is reduced by establishing symbiotic relationships on waste heat utilization to some extent. According to investigation, during this stage, the demand for electricity and steam in HHIS slowly increased because of the relatively slow increase of production output of HHG. From 2003 to 2008, curves 1 to 6 all show a clear upward trend, which indicates that energy consumption in HHIS significantly increased. At this stage, the output of the major products, such as soda and salt, rapidly increased. Furthermore, some new companies were built, such as the petrochemical company and the chlor-alkali colophony plant. Therefore, the demand for steam and electricity rapidly increased, which led to a rapid increase in energy consumption. Curves 1 and 5 are above curve 6 at this stage, which indicates that the symbiotic relationship on waste heat utilization still played a role in reducing energy consumption. However, it can be seen that it did not significantly reduce the energy consumption. From 2008 to 2017, curves 1 to 4 , and curve 6 are all below curve 5. Curves 1 and 3 are both above curve 6 (curve 6 
coincides with curve 4 from 2008 to 2012), and show a downward trend. This indicates that in addition to waste heat utilization, the symbiotic relationship on flare gas utilization established in 2008 also contributed to reducing the energy consumption of HHIS. From 2008 to 2015, curve 2 is above and far from curve 6 . This indicates that the symbiotic relationship regarding off-gas carbon black utilization, which was established between the second power plant (the branch of the thermal power plant) and the carbon black plant in 2008, significantly reduced the energy consumption of HHIS. After 2015, curve 2 coincides with curve 6 . The reason is that the HHG shut down the second power plant in 2005 in order to adjust and optimize the industrial structure and eliminate outdated equipment, which led to the termination of the symbiotic relationship between the second power plant and the carbon black plant. After 2012, curve 4 is above curve 6, and the gap between the two curves gradually increased. The reason is that the symbiotic relationship regarding hydrogen utilization was established between the thermal power plant and the chlor-alkali colophony plant in 2012, and the amount of hydrogen utilized gradually increased. From the figure, it can be seen that the establishment of the symbiotic relationship involving hydrogen utilization played a key role in reducing the energy consumption of HHIS.

The drivers and their effects on the symbiotic relationships on energy utilization are shown in Table 5.

Table 5. The drivers and their effects on the symbiotic relationships on energy utilization. HHG: Hai Hua Group.

\begin{tabular}{|c|c|c|}
\hline Drivers & $\begin{array}{l}\text { Symbiotic Relationships on } \\
\text { Energy Utilization }\end{array}$ & Effects \\
\hline Government & Waste heat utilization & $\begin{array}{l}\text { The HHG was established based on the combination of the salt field and soda plant issued } \\
\text { by the government, which directly promoted the establishment of symbiotic relationships, } \\
\text { including waste heat utilization between the two companies, and became a starting point } \\
\text { for the development of HHIS [67]. }\end{array}$ \\
\hline Company & $\begin{array}{l}\text { Waste heat utilization } \\
\text { Off-gas carbon black utilization } \\
\text { Flare gas utilization } \\
\text { Hydrogen utilization }\end{array}$ & $\begin{array}{l}\text { With the evolution of HHIS, the companies understanding of IS was gradually enhanced. } \\
\text { IS awareness has been integrated into the culture of HHG. This drives companies to } \\
\text { actively identify the potential symbiotic relationships regarding energy utilization and } \\
\text { seek appropriate technology to establish these symbiotic relationships. }\end{array}$ \\
\hline \multirow{4}{*}{ Economy } & Waste heat utilization & $\begin{array}{l}\text { Economic benefits achieved from the symbiotic relationships on energy utilization directly } \\
\text { promoted the establishment of these symbiotic relationships, which include: } \\
\text { more than } 20 \text { million Yuan/a of economic benefits can be achieved by waste heat } \\
\text { utilization, which stimulated companies to seek more opportunities of symbiotic relations. }\end{array}$ \\
\hline & Off-gas carbon black utilization & $\begin{array}{l}5485 \text { ton/a of coal can be saved and } 18 \text { million Yuan/a of economic benefits can be } \\
\text { achieved by off-gas carbon black utilization. }\end{array}$ \\
\hline & Flare gas utilization & $\begin{array}{l}1932 \text { ton/a of coal can be saved and } 1.4 \text { million Yuan/a of economic benefits can be } \\
\text { achieved by flare gas combustion. }\end{array}$ \\
\hline & Hydrogen utilization & 40 million Yuan/a of economic benefits can be achieved by hydrogen utilization. \\
\hline Technology & $\begin{array}{l}\text { Off-gas carbon black utilization } \\
\text { Flare gas utilization } \\
\text { Hydrogen utilization }\end{array}$ & $\begin{array}{l}\text { In order to effectively utilize off-gas carbon black, flare gas, and hydrogen, the HHG } \\
\text { investigated related technologies and found that the combustion technology of off-gas } \\
\text { carbon black, flare gas, and hydrogen for power generation is mature and safe, } \\
\text { which promoted the establishment of symbiotic relationships utilizing these combustible } \\
\text { exhaust gases. }\end{array}$ \\
\hline
\end{tabular}

\subsubsection{Solid Waste Stock Analysis}

The scenario analysis of solid waste is shown in Table 6. Based on the simulation of four scenarios, the results of solid waste stock during the evolutionary process of HHIS is shown in Figure 5. 
Table 6. The scenario analysis of solid waste in HHIS.

\begin{tabular}{|c|c|c|c|}
\hline Scenario & Fly Ash Utilization Rate & $\begin{array}{c}\text { Carbide Slag } \\
\text { Utilization Rate }\end{array}$ & $\begin{array}{l}\text { Caustic Sludge } \\
\text { Utilization Rate }\end{array}$ \\
\hline Current-curve 4 & 1.0 & $\begin{array}{l}0(1995 \sim 2004) \\
1(2005 \sim 2011) \\
0(2012 \sim 2017)\end{array}$ & 0 \\
\hline Scenario 1-curve 1 & 0 & $\begin{array}{l}0(1995 \sim 2004) \\
1(2005 \sim 2011) \\
0(2012 \sim 2017)\end{array}$ & 0 \\
\hline Scenario 2-curve 2 & 1.0 & 0 & 0 \\
\hline $\begin{array}{c}\text { Scenario 3-curve } 3 \\
\text { (No IS on solid waste utilization) }\end{array}$ & 0 & 0 & 0 \\
\hline
\end{tabular}

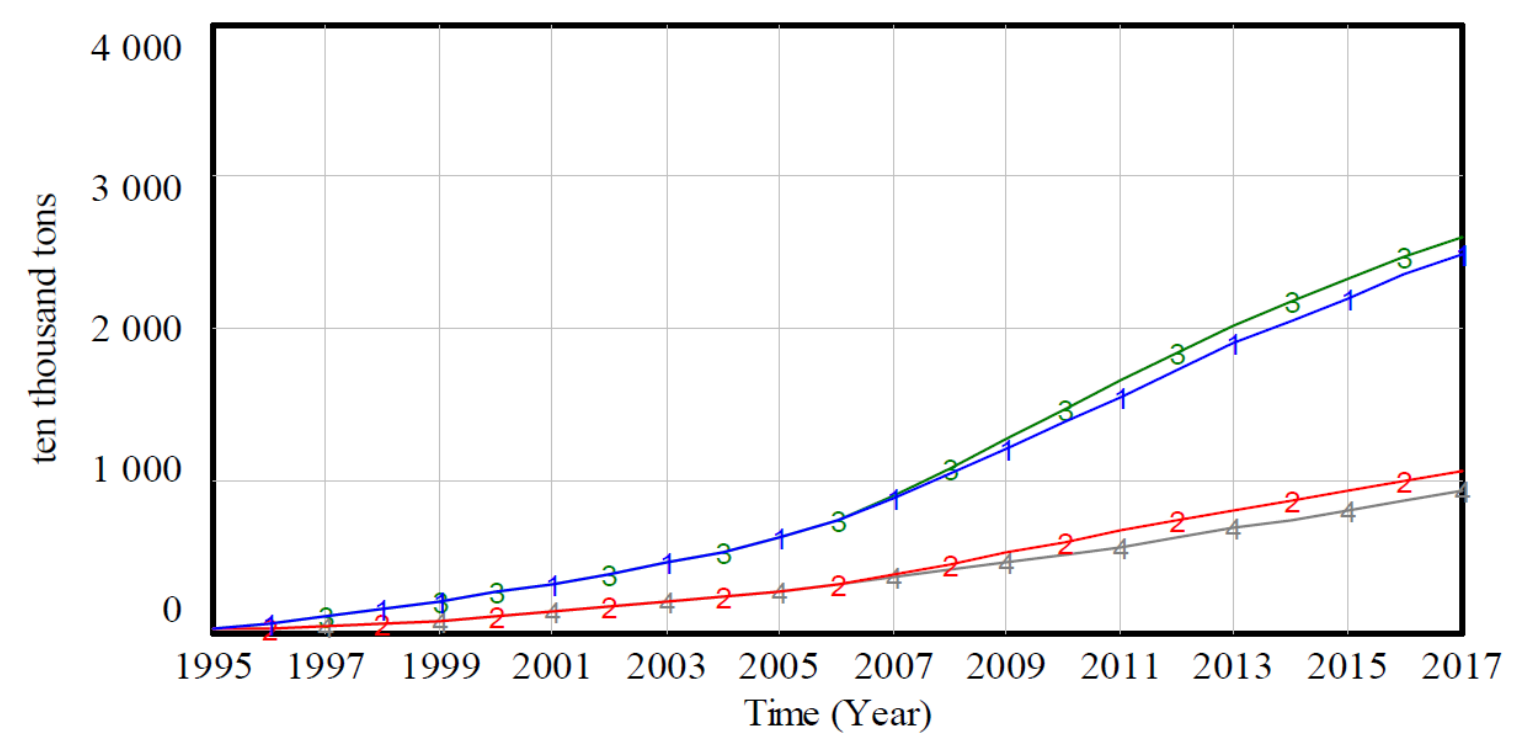

Solid Waste : scenario 1 Solid Waste : scenario 2

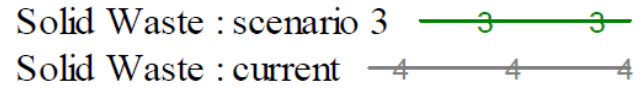

Figure 5. The trends of solid waste stock in HHIS.

From 1995 to 2005, curve 1 coincides with curve 3, because no symbiotic relationships existed during this period in the two scenarios. Curve 2 coincides with curve 4 . The reason is that there were no other symbiotic relationships on solid waste utilization established, except for the symbiotic relationship utilizing fly ash between the thermal power plant and the cement plant during this stage. From 1995 to 2003, the growth trend of curves 1 to 4 is relatively flat, which indicates that the growth of solid waste was slow, because the output of the main products of HHG slowly increased during this period. Curve 1 is higher than curve 4, which indicates that the solid waste stock in HHIS was reduced by fly ash utilization. Curve 4 still shows a growth trend, which was mainly because of the unutilized caustic sludge in HHIS. After 2003, curves 1 to 4 all show an obvious growth trend, especially curve 1 and curve 3. The reason is that the demand for electricity and steam from the thermal power plant increased because of the establishment of new companies and the substantial increase in the product output of the HHG, which led to the increase in the amount of fly ash. Meanwhile, the output of soda substantially increased, which made the caustic sludge increase accordingly. At this stage, the difference between curve 1 and curve 4 is relatively large, which indicates that the establishment of a symbiotic relationship on fly ash utilization played an important role in reducing the solid waste stock in HHIS. After 2005, curve 2 is above curve 4. This indicates that the carbide slag utilization that was established in 2005 contributed to reduce the solid waste stock in HHIS to some extent. 
After 2011, the slopes of curve 2 and curve 4 are exactly the same, which indicates that changing the utilization rate of carbide slag had no effect on the solid waste stock. The reason is that the chlor-alkali colophony plant stopped producing PVC in 2012 due to the fierce competition in the PVC market, which stopped the generation of calcium carbide. The solid waste stock in HHIS is completely caused by the unutilized caustic sludge.

The drivers and their effects on the symbiotic relationships regarding solid waste utilization are shown in Table 7.

Table 7. The drivers and their effects on the symbiotic relationships regarding solid waste utilization.

\begin{tabular}{|c|c|c|}
\hline Drivers & $\begin{array}{l}\text { Symbiotic Relationships on } \\
\text { Solid Waste Utilization }\end{array}$ & Effects \\
\hline Company & $\begin{array}{l}\text { Fly ash utilization } \\
\text { Carbide slag utilization }\end{array}$ & $\begin{array}{l}\text { During the evolution process of HHIS, the companies' understanding } \\
\text { of IS has been continuously improved. IS awareness was integrated into } \\
\text { the culture of the HHG, which was reflected in the planning of the } \\
\text { HHG. This drives companies to identify potential symbiotic } \\
\text { relationships regarding the utilization of fly ash and carbide slag, } \\
\text { and seek appropriate technologies. Utilizing the carbide slag generated } \\
\text { in PVC production to substitute limestone as a raw material for } \\
\text { producing soda was planned by the HHG before the establishment of } \\
\text { the chlor-alkali colophony plant. }\end{array}$ \\
\hline \multirow[t]{2}{*}{ Economy } & Fly ash utilization & $\begin{array}{l}\text { Economic benefits achieved by the symbiotic relationships on solid } \\
\text { waste directly promoted the establishment of these symbiotic relations, } \\
\text { which includes: } \\
\text { about } 1 \text { million Yuan/a of economic benefits can be achieved by fly ash } \\
\text { utilization. }\end{array}$ \\
\hline & Carbide slag utilization & $\begin{array}{l}\text { 150,000 ton/a of limestone can be saved and more than } 40 \text { million } \\
\text { Yuan/a of economic benefits can be realized by carbide slag utilization. }\end{array}$ \\
\hline Technology & Carbide slag utilization & $\begin{array}{l}\text { The HHG successfully developed the technology of replacing limestone } \\
\text { with carbide slag as raw material for producing soda, which solved the } \\
\text { problem of carbide slag utilization. }\end{array}$ \\
\hline
\end{tabular}

\subsubsection{Wastewater Stock Analysis}

The comprehensive utilization of the wastewater of HHIS can be divided into two aspects. (1) First, the wastewater that is generated from one company can be reused as a resource by other companies. For example, the bittern brine that is generated in the salt field and the waste ammonia liquid that is produced by the soda plant can be reused as raw materials in the potassium sulfate plant and calcium chloride plant, respectively. (2) Wastewater can be recycled. For example, the steam condensate returns to the thermal power plant for reuse, and the industrial wastewater from the soda plant and thermal power plant is collected centrally and reused for ash-flushing, salt-dissolving, and circulating water.

The scenario analysis of wastewater is shown in Table 8. From the simulation of the five scenarios, the results of wastewater stock within HHIS is shown in Figure 6.

Table 8. The scenario analysis of waste water in HHIS.

\begin{tabular}{|c|c|c|c|}
\hline Scenario & $\begin{array}{l}\text { Recycling Rate of } \\
\text { Wastewater }\end{array}$ & $\begin{array}{l}\text { Waste Ammonia Liquid } \\
\text { Utilization Rate }\end{array}$ & $\begin{array}{c}\text { Bittern Brine } \\
\text { Utilization Rate }\end{array}$ \\
\hline Current-curve 5 & table function ${ }^{2}$ & $\begin{array}{c}0(1995 \sim 1996) \\
0.87(1997 \sim 2017)\end{array}$ & 1.0 \\
\hline Scenario 1-curve 1 & 0 & $\begin{array}{c}0(1995 \sim 1996) \\
0.87(1997 \sim 2017)\end{array}$ & 1.0 \\
\hline Scenario 2-curve 2 & table function & 0 & 1.0 \\
\hline Scenario 3-curve 3 & table function & $\begin{array}{c}0(1995 \sim 1996) \\
0.87(1997 \sim 2017)\end{array}$ & 0 \\
\hline $\begin{array}{c}\text { Scenario 4-curve } 4 \\
\text { (No IS on waste water utilization) }\end{array}$ & 0 & 0 & 0 \\
\hline
\end{tabular}

${ }^{2}$ Table function can be seen in Appendix A. 


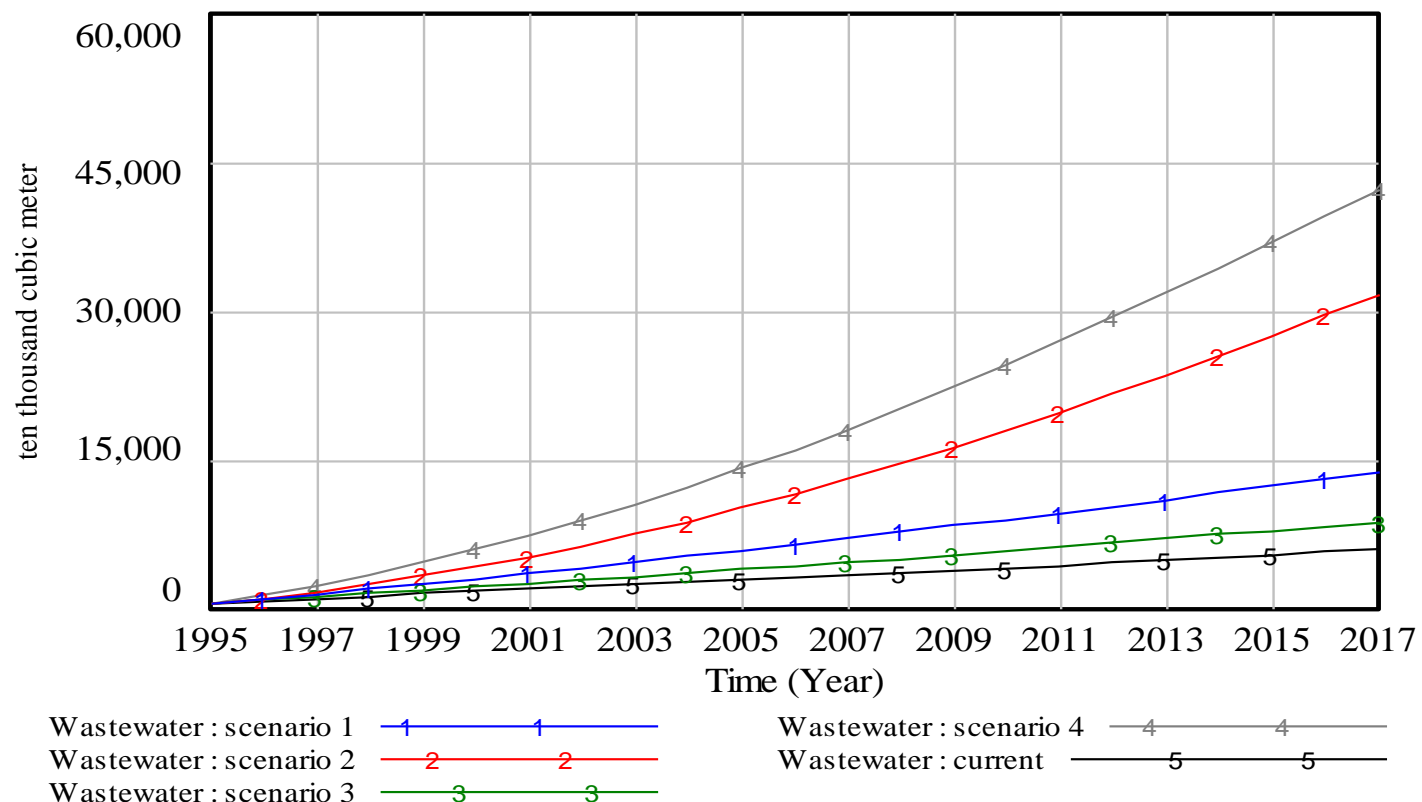

Figure 6. The trends of wastewater stock in HHIS.

From 1995 to 2003, the growth of curves 1 to 5 is relatively slow. At this stage, the growth of the product output of HHG was relatively slow, which resulted in a relatively slow growth of wastewater generated. Curve 1 and curve 3 are above curve 5, which indicates that establishing symbiotic relationships regarding wastewater recycling and bittern brine utilization contributed to reducing the wastewater stock in HHIS to some extent. From 1995 to 1996, the utilization of waste ammonia liquid had not yet begun. This results in the overlap of curve 2 and curve 5 from 1995 to 1996. After 1996, curve 2 is above curve 5, which indicates that the symbiotic relationship regarding waste ammonia liquid utilization effectively reduced the wastewater stock in HHIS. From 2003 to 2017, curves 1 to 4 all show a relatively obvious upward trend, especially curve 2 and curve 4 . This indicates that the wastewater stock in HHIS continued to increase at this stage. The main reason is that with the increase of the product output in HHG, the quantity of bittern brine, waste ammonia liquid, and other industrial wastewater all increased correspondingly. Especially with the substantial increase in the soda output, the output of waste ammonia liquid greatly increased. Curves 1 to 4 are all above curve 5 , which indicates that the wastewater stock was effectively reduced by establishing the symbiotic relationships regarding wastewater recycling and the utilization of bitter brine and waste ammonia liquid. Particularly, the waste ammonia liquid utilization had a significant effect on reducing wastewater stock in HHIS. For this reason, the large quantity of waste ammonia liquid generated from the soda plant does not lead to a significant increase of wastewater stock. Curve 5 still shows a slight increase. This is mainly because the calcium chloride plant often has low economic benefits because of the fierce market competition, and as a result, the waste ammonia liquid cannot be utilized in a timely manner, and has to be temporarily stored in the field where it evaporates, thus leading to a slow growth of wastewater stock in HHIS.

The drivers and their effects on the symbiotic relationships on wastewater utilization are shown in Table 9. It can be seen that utilization of waste ammonia liquid and bittern brine are both driven by many drivers, including the government, the companies, the economy, and technology. 
Table 9. The drivers and their effects on the symbiotic relationships regarding wastewater utilization.

\begin{tabular}{|c|c|c|}
\hline Drivers & $\begin{array}{l}\text { Symbiotic Relationships on } \\
\text { Wastewater Utilization }\end{array}$ & Effects \\
\hline Government & $\begin{array}{l}\text { Wastewater recycling } \\
\text { Waste ammonia liquid utilization } \\
\text { Bittern brine utilization }\end{array}$ & $\begin{array}{l}\text { The policy of salt-soda combination contributes to the establishment of } \\
\text { symbiotic relationships between the soda plant and the thermal power } \\
\text { plant regarding wastewater recycling. } \\
\text { The utilization of waste ammonia liquid and bittern brine have been } \\
\text { supported by the government policy. It is the project of national } \\
\text { resource comprehensive utilization, which covers the tax cuts and } \\
\text { refund policies for the utilization of waste ammonia liquid and } \\
\text { bittern brine. }\end{array}$ \\
\hline Resource & Wastewater recycling & $\begin{array}{l}\text { The shortage of freshwater in the area where HHIS is located motivates } \\
\text { companies to establish symbiotic relationships regarding effectively } \\
\text { utilizing freshwater. }\end{array}$ \\
\hline Company & $\begin{array}{l}\text { Wastewater recycling } \\
\text { Waste ammonia liquid utilization } \\
\text { Bittern brine utilization }\end{array}$ & $\begin{array}{l}\text { In the evolution process of HHIS, the companies' understanding on IS } \\
\text { is continuously raised. IS awareness has integrated into the culture of } \\
\text { HHG, which drives companies to actively identify the potential } \\
\text { symbiotic relationships regarding wastewater utilization and seek } \\
\text { appropriate technology to establish these symbiotic relationships. }\end{array}$ \\
\hline \multirow[t]{3}{*}{ Economy } & Wastewater recycling & $\begin{array}{l}\text { Economic benefits achieved from the symbiotic relationships regarding } \\
\text { wastewater utilization directly promoted the establishment of these } \\
\text { symbiotic relationships, which includes: } \\
\text { more than } 600,000 \mathrm{~m}^{3} / \mathrm{a} \text { of freshwater being saved and } 1.2 \text { million } \\
\text { Yuan/a of economic benefits being achieved by recycling wastewater. }\end{array}$ \\
\hline & Waste ammonia liquid utilization & $\begin{array}{l}20 \text { million Yuan/a of economic benefits can be realized by waste } \\
\text { ammonia liquid utilization. }\end{array}$ \\
\hline & Bittern brine utilization & $\begin{array}{l}16 \text { million Yuan/a of economic benefits can be achieved through bittern } \\
\text { brine utilization. }\end{array}$ \\
\hline Technology & $\begin{array}{l}\text { Waste ammonia liquid utilization } \\
\text { Bittern brine utilization }\end{array}$ & $\begin{array}{l}\text { In order to make full use of waste ammonia liquid and bittern brine, } \\
\text { the HHG cooperates with universities and research institutions to } \\
\text { develop technology on the utilization of ammonia waste liquid and } \\
\text { bittern brine, which provides the technical support for establishing } \\
\text { related symbiotic relationships. }\end{array}$ \\
\hline
\end{tabular}

\subsubsection{Symbiotic Benefits Analysis}

Through the scenario analysis of energy consumption, solid waste, and wastewater, the changes of symbiotic benefits in the evolution process of HHIS can be seen in Figures 7-9.

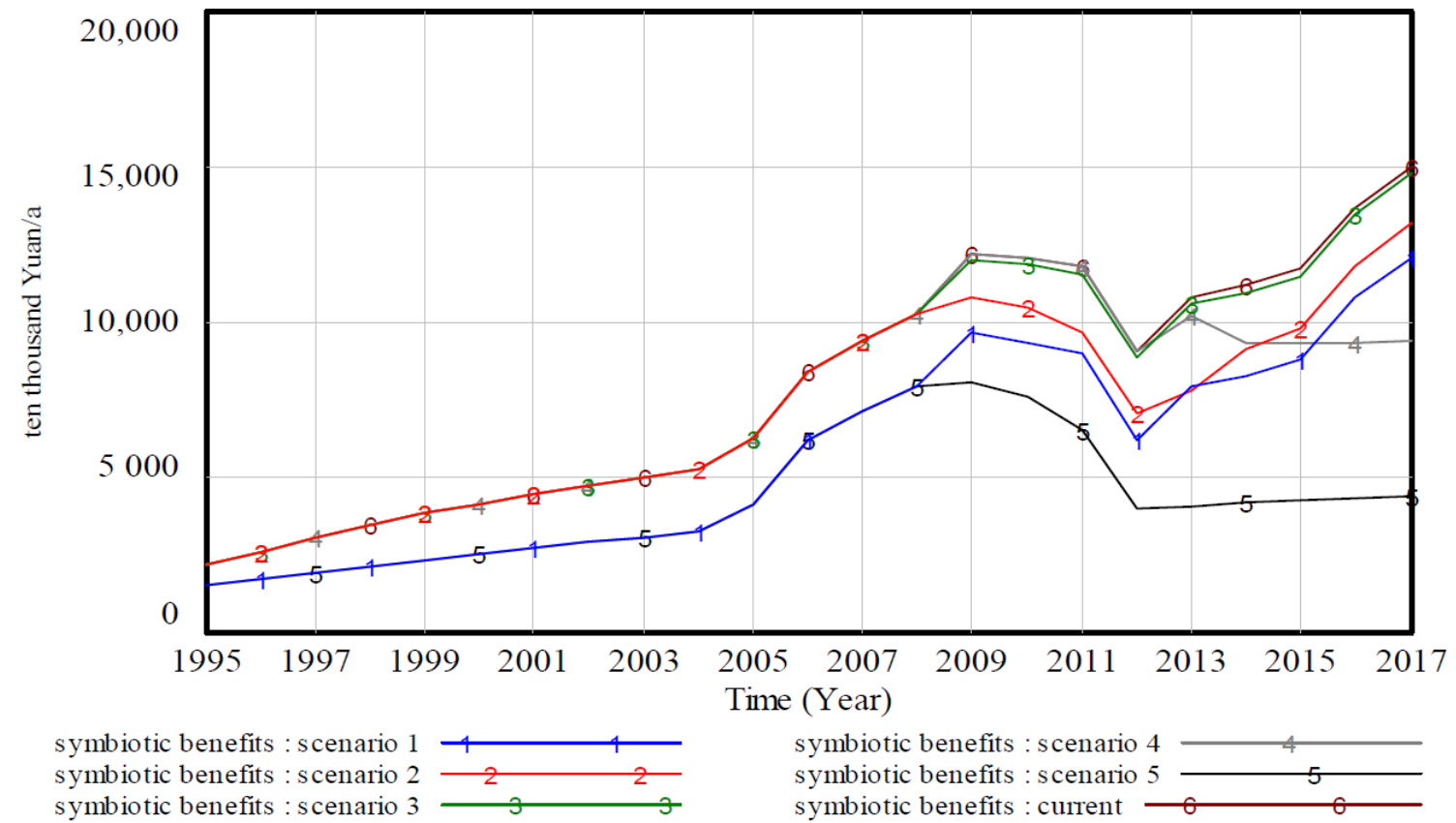

Figure 7. The trends of symbiotic benefits under the scenario analysis of energy consumption. 


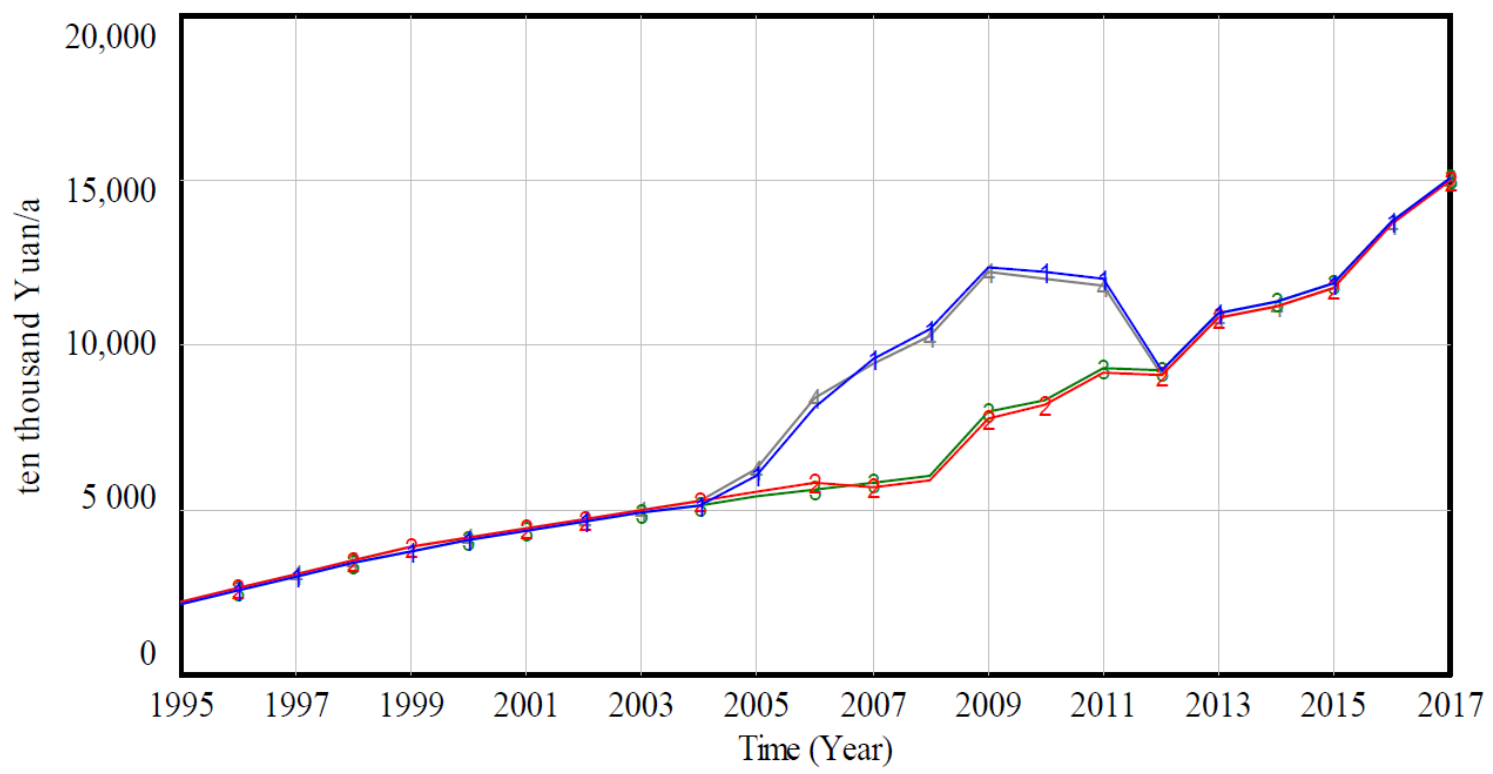

symbiotic benefits : scenario 1 symbiotic benefits : scenario 2

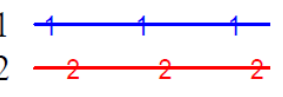

symbiotic benefits : scenario 3 つ symbiotic benefits : current

Figure 8. The trends of symbiotic benefits under the scenario analysis of solid waste.

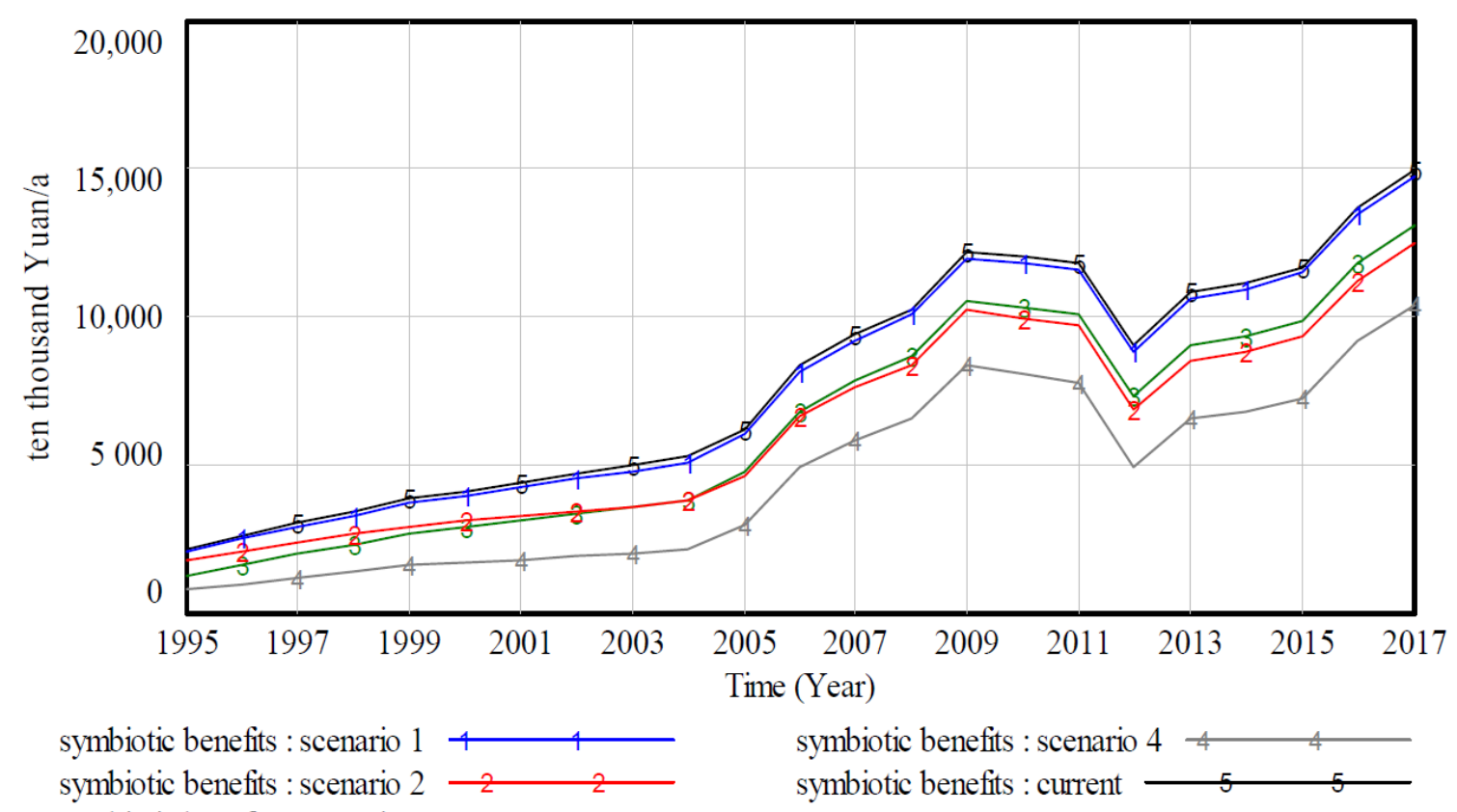

symbiotic benefits : scenario 3

Figure 9. The trends of symbiotic benefits under the scenario analysis of wastewater.

In Figure 7, from 1995 to 2008, curve 1 and curve 5 are below curve 6 . The reason is that in terms of energy utilization, symbiotic benefits were only achieved by waste heat utilization from 1995 to 2008 . Other symbiotic relationships on energy utilization were not established; thus, there were no symbiotic benefits generated. After 2008, there is a gap between curves 1 to 3 and curve 6, which indicates that the symbiotic relationships regarding the utilization of waste heat, off-gas carbon black, and flare gas all brought good symbiotic benefits. The symbiotic relationship regarding hydrogen utilization that was established in 2012 achieved significant economic benefits, which made the system re-emerge in the growth trend after the decrease from 2011 to 2012, which was caused by the disconnection of the symbiotic relationship regarding carbide slag utilization. 
In Figure 8, from 1995 to 2007, curve 4 is above curve 1 (curve 4 coincides with curve 2 and curve 1 coincides with curve 3 from 1995 to 2004, because carbide slag utilization had not yet begun), which indicates that fly ash utilization brought symbiotic benefits the entire time during this stage. After 2007, curve 1 is above curve 4, which indicates that the symbiotic relationship regarding fly ash utilization did not result in economic benefits. The reason is that under the pressure of China's increasingly strict environmental protection policy, the HHG closed the cement plant in 2007 because of the potential air pollution when storing and utilizing the fly ash. Thus, the fly ash was not available to be utilized within HHIS. In order to dispose of the fly ash, the HHG provided it to companies outside the region where HHIS is located with no charge and covers the transportation costs. Since the fly ash is utilized outside the region, it no longer brings symbiotic benefit to HHIS. Furthermore, the transportation costs undertaken by the HHG are higher than the symbiotic benefits achieved by the carbide slag utilization, which makes curve 3 higher than curve 2 after 2007. The reason is that the symbiotic relationship regarding carbide slag utilization that was established in 2005 was beneficial to HHIS. However, the chlor-alkali colophony plant stopped producing PVC in 2012 due to the fierce competition in the PVC market, which led to the disconnection of the symbiotic relationship regarding carbide slag utilization. Therefore, there is no symbiotic benefit achieved by carbide slag utilization, thus leading to a decline in the economic benefit from 2011 to 2012.

In Figure 9, curve 5 is above curves 1 to 4 from 1995 to 2017, indicating that in terms of wastewater utilization, the symbiotic relationships regarding wastewater recycling, waste ammonia liquid utilization, and bittern brine utilization all brought positive symbiotic benefits.

In general, from the actual trend of the symbiotic benefits in HHIS, i.e., curve 6 of Figure 7, curve 4 of Figure 8, and curve 5 of Figure 9, all show a growth trend on the whole. This indicates that in the evolutionary process of HHIS, the benefits achieved by symbiotic relationships on the utilization of energy, solid waste, and wastewater all show a gradual increasing trend. From 1995 to 2003, the symbiotic benefits slightly increased. The reason is that at the early stage of HHIS, there were fewer symbiotic companies and symbiotic chains, and the output of products, by-products, and wastes were relatively low, thus leading to a slow growth of symbiotic benefits. From 2011 to 2012, the symbiotic benefits showed a clear downtrend due to the discontinuation of PVC production. However, it quickly changed. From 2003 to 2017, the growth rate of the symbiotic benefits accelerated, and the symbiotic benefits rapidly increased. Under the influence of the circular economy and IS, new companies and symbiotic relationships were established. At the same time, the output of products rapidly increased. The output and utilization of by-products and wastes increased correspondingly. Thus, the symbiotic benefits generally showed a rapid growth trend at this stage.

Based on the above analysis, it can be seen that the SD model that was used in this paper helped show the effects and benefits and their changes on reducing the energy consumption, solid waste stock, and wastewater stock that was achieved through establishing symbiotic relationships during the evolution of HHIS. The results indicate that the curves of the solid waste stock and wastewater stock still showed a slight increase under the current scenario. Compared with other scenarios, the stock of solid waste and wastewater, as well as that of energy consumption, were effectively reduced. Furthermore, the symbiotic benefits showed a growth trend on the whole. This demonstrates that establishing symbiotic relationships assists in making an IS evolve toward a win-win situation. From a life cycle perspective, some researchers [3,73] concluded in their studies that life cycle assessment is a useful tool for effectively quantifying the environmental performance of an IS through choosing several reference scenarios.

The model in this paper helps look at an IS from a long-term evolutionary process, evolving from 1995 to 2017, which includes more than 20 years of evolution. Two state variables, i.e., solid waste stock and wastewater stock, were chosen to characterize the utilization of material and reduction of wastes during the evolution of HHIS. Greenhouse gas (GHG) emissions are an important topic to be explored in the field of IS [74]. The $\mathrm{CO}_{2}$ emissions could be added to the SD model as an additional state variable in future research. The drivers are not introduced into the SD model. However, they are 
used to analyze the results of the model, which is helpful for better understanding the evolutionary path and characteristics of HHIS. It can be addressed that the model in this paper may help deepen our understandings of key actors in industrial symbioses. Both the soda plant and the thermal power plant are key companies in HHIS, which established symbiotic relationships on energy cascading and water cascading with other companies at the early stages of evolution in HHIS. During the evolutionary process, they gradually utilized wastes from other companies, such as the carbide slag and the off-gas carbon black, which played a critical role in reducing the energy consumption and solid waste stock for the whole IS. This means that the functions of the two key companies gradually expanded with the evolution of HHIS.

\subsection{Findings}

\subsubsection{The Gradual Awareness-Raising of IS}

During the evolution process of HHIS, it can be seen that the industrial symbiotic relationships established regarding the utilization of energy, solid waste, and wastewater were all driven in part by participating companies' gradual awareness-raising of IS. This is helpful for reducing the energy consumption, the solid waste stock, and the wastewater stock, and can be seen from the scenario analysis. With the establishment of symbiotic relationships based on salt-soda, companies realized that a win-win situation between the economy and the environment could be achieved by IS. This changed the understanding of by-products and wastes. Then, IS was gradually integrated into the culture of those companies. The project planning of HHG is guided by IS.

For example, the symbiotic relationship based on carbide slag utilization between the soda plant and the chlor-alkali colophony plant was planned before the construction of the chlor-alkali colophony plant. From the scenario analysis of solid waste, it shows that carbide slag utilization contributed to reducing the solid waste stock in HHIS. Furthermore, companies consciously uncovered and established more symbiotic relationships. For example, the off-gas carbon black from the carbon black plant was utilized by the power plant, which significantly reduced the energy consumption of HHIS. Even though some disappeared due to the market changes, new symbiotic relationships were established in order to utilize these by-products or wastes. For example, the hydrogen from the chlor-alkali colophony plant was once piped to Tian Xiang chemical plant for producing phenylamine. This symbiotic relationship disappeared later, because Tian Xiang chemical plant was closed because of market changes. However, a new symbiotic relationship based on hydrogen was established, which piped the hydrogen from the chlor-alkali colophony plant to the thermal power plant, and thus substantially reduced the energy consumption of HHIS. Thus, it can be considered that the evolution of HHIS is a process of gradual awareness-raising of IS, which is helpful for promoting the evolution of HHIS.

\subsubsection{Uncovering and Improving the Function of Scavengers}

Scavenger and decomposer companies play a key role in the development of IS [75]. During the evolution process of HHIS, it can be found that the function of the scavenger was gradually enhanced, and more companies serving as scavengers have been gradually uncovered. From the scenario analysis, we can see that most of the waste or by-products that appeared during the evolution process of HHIS could be effectively utilized by scavengers, which greatly contributed to reducing energy consumption, solid waste stock, and wastewater stock. On the one hand, scavenger companies were established, such as the potassium sulfate plant and the calcium chloride plant. The scenario analysis of wastewater showed that both of them contributed to reducing wastewater levels. One the other hand, the scavenger function of some companies was identified. For example, both the thermal power plant and the soda plant were not previously scavengers. However, during the evolution process, the thermal power plant gradually utilized the combustible flue gas, including off-gas carbon black, flare gas, and hydrogen from other companies, which facilitated a reduction in the energy consumption. The role of the soda 
plant serving as a scavenger company was also uncovered, which utilized the carbide slag from the chlor-alkali colophony plant and reduced the solid waste. Although with the substantial increase of product output in the HHG, the quantity of waste greatly increased correspondingly, the energy consumption and waste stock did not show a similar trend, because of the role of those scavengers. Thus, it can be seen that the evolutionary process of IS can be seen as a process of identifying more scavenger companies, which assists in utilizing more by-products and wastes over time.

\subsubsection{The Important Role Played by Government Policies during the Evolution of HHIS}

Under the push of the salt-soda combination policy, the symbiotic relationships between the salt field and the soda plant were established, which was a starting point for HHIS [36]. This suggests that the policy played a direct role in the establishment of HHIS. Thereafter, the government still provided policies to promote the development of HHIS. Especially for some scavenger companies, policies played a critical role in maintaining their smooth operation. For example, with the substantial increase in the soda output, the output of waste ammonia liquid greatly increased. The tax preference policy introduced by the government assisted in encouraging the calcium chloride plant and the potassium sulfate plant to utilize the waste ammonia liquid and bittern brine, respectively, and greatly reduced the wastewater stock for HHIS, which played an important role in fostering the evolution of HHIS.

\subsubsection{The Dynamic Process of HHIS Evolution}

During the evolutionary process of HHIS, the quantity of waste and by-products changed. The economic development of HHIS was achieved by a large increase in production, which correspondingly led to a significant increase of waste. From the results of the model, we can see that the utilization of some wastes, such as fly ash and waste ammonia liquid, had been increased accordingly through establishing symbiotic relationships. In addition, the types of wastes and by-products also changed. New companies were established, which often generated new wastes or by-products. In HHIS, this included the establishment of a petrochemical company that produced flare gas. Through establishing a symbiotic relationship with the thermal power plant, the flare gas was utilized, which also resulted in the reduced energy consumption of HHIS. Some waste or by-product will be influenced because of the changed symbiotic relationship. This requires efforts to seek new symbiotic relationships over time. For example, because the Tian Xiang chemical plant closed, hydrogen from the chlor-alkali colophony was provided to the thermal power plant, which showed effective results for significantly reducing the energy consumption of HHIS.

\subsection{Challenges}

While favorable results have been achieved during the evolution of HHIS, there are still some challenges that restrict the further evolution of HHIS.

From the results of the SD model in this paper, it can be seen that solid waste stock was effectively reduced through establishing symbiotic relationships during the evolution process in HHIS. However, the curve of the current scenario of solid waste stock still shows a growth trend. This is because of the unutilized caustic sludge. The caustic sludge utilization is a difficult problem both for HHG and the entire ammonia soda industry in China. Although HHG has carried out relevant research in cooperation with universities and research institutes, there is still no applicable technology for utilizing caustic sludge. At present, the caustic sludge has to be temporarily stacked in residue fields, which could lead to land contamination and security problems. Therefore, through the lens of drivers for promoting the evolution of HHIS, the government should formulate special policies at the national level aimed at promoting the utilization of caustic sludge, such as providing special research funds for caustic sludge utilization, promoting cooperation among the entire ammonia soda industry, universities, and research institutes to develop technologies regarding caustic sludge utilization, and offering preferential incentives for utilizing caustic sludge. 
HHIS is faced with a challenge caused by the instability of government policies on the waste ammonia liquid utilization. The tax cuts and refund policies on calcium chloride introduced by the government were helpful for encouraging the waste ammonia liquid to be utilized in HHIS. The calcium chloride plant often has low economic benefits because of the fierce market competition, which often makes the waste ammonia liquid unable to be utilized in time. For this reason, although waste ammonia liquid has been utilized, which has a significant effect on reducing the wastewater stock during the evolution process of HHIS, the curve of the current scenario of wastewater stock still shows a slight increase. Thus, the government policies on calcium chloride are essential for maintaining the utilization of waste ammonia liquid. However, this policy was not stably implemented. In 2015, the government removed the tax preference policy on calcium chloride production, which utilizes waste ammonia liquid as raw material, and intensified the support for calcium chloride produced by waste acid at the same time. However, the cost of producing calcium chloride utilizing waste acid is always much lower than that of producing calcium chloride with waste ammonia liquid. For this reason, the calcium chloride plant in HHIS is at a more adverse situation in relation to market competition. Thus, the government should fully understand the actual situation of companies, and improve its supportive policies to stimulate enterprises to make full use of waste ammonia liquid. These supportive policies need to be stably implemented.

The low-carbon economy is one of the key factors contributing to sustainable development [76]. The energy structure of HHIS is still dominated by coal. Through the scenario analysis of energy consumption, it can be seen that combustible waste gas, including flare gas, off-gas carbon black, and hydrogen has been utilized through establishing symbiotic relationships, which contribute to reducing energy consumption in HHIS. However, from the low-carbon perspective, the combustion of flare gas and off-gas carbon black still discharges carbon dioxide. Compared with flare gas and off-gas carbon black, combusting hydrogen plays a key role in reducing the energy consumption of HHIS and does not produce carbon dioxide. In order to achieve a low-carbon economy, HHIS should identify potential possibilities to make full use of low-carbon energy during the future evolution process. For example, based on the local advantage of a coastal beach land, solar energy can be vigorously developed in the future.

\section{Conclusions}

The SD model that was put forward in this paper can be used to uncover and analyze the evolutionary path of IS. Choosing different scenarios through simulation, the model assists in visualizing the effects and benefits of reducing energy consumption, solid waste stock, and wastewater stock achieved by establishing symbiotic relationships during the evolution of HHIS. The information shows that positive results have been achieved in the utilization of energy, solid waste, and wastewater through establishing symbiotic relationships. The drivers for promoting the evolution of IS were introduced in the study and used to analyze the results of the model, which is helpful for better understanding the evolutionary path and characteristics of HHIS. The SD model in this paper focused on two level variables, including the stock of solid waste and wastewater. Considering the issue of climate change, GHG emissions, such as the $\mathrm{CO}_{2}$ emissions, could be added to the SD model as an additional level variable in future research. In addition, the drivers for IS evolution were qualitatively used in this study. How to quantitatively identify the roles played by different drivers could be an interesting question related to the topic of IS evolution. This study is based on a case study in China. However, the model that was introduced should provide guidance for understanding the evolution of other industrial symbioses, and could be used in more IS cases.

Author Contributions: C.L. conceived the research idea and designed the general framework of the research; H.C. built SD model and analyzed the data. H.C. and C.L. collected the data and drafted the paper. R.C. provided comments and revised the paper. W.L. provided suggestions on building the SD model.

Funding: The financial support provided by the National Natural Science Foundation of China (41471458) and the Foundation of Beijing Institute of Technology (20151042003) is acknowledged. 
Acknowledgments: We acknowledge the Environmental Protection Bureau of Weifang Binhai Economic and Technological Development Zone (WBETDZ), Hai Hua Group (HHG) and the companies involved in the case study for their great help and the data they provided. Finally, we thank the anonymous reviewers for their constructive comments for improving the paper.

Conflicts of Interest: The authors declare no conflict of interest.

\section{Appendix}

Table functions are described as follows:

1. Waste heat utilization $=$ WITH LOOKUP $($ Time, $([(1995,0)-(2017,91)],(1995,20),(1999,45)$, $(2004,60),(2008,70),(2011,85),(2016,87),(2017,91)))$

2. off-gas carbon black utilization = WITH LOOKUP (Time, $([(1995,0)-(2017,19078)],(1995,0)$, $(1996,0),(1997,0),(1998,0),(1999,0),(2000,0),(2001,0),(2002,0),(2003,0),(2004,0),(2005,0)$, $(2006,0),(2007,0),(2008,0),(2009,13740),(2010,15588),(2011,21285),(2012,19901),(2013,29962)$, (2014.05,19736), (2015,18859), (2016,18201), (2017,19078)))

3. Flare gas utilization $=$ WITH LOOKUP $($ Time,$([(1995,0)-(2017,221)],(1995,0),(1996,0),(1997,0)$, $(1998,0),(1999,0),(2000,0),(2001,0),(2002,0),(2003,0),(2004,0),(2005,0),(2006,0),(2007,0)$, $(2008,11.8),(2009,224.2),(2010,156.9),(2011,259.2),(2012,214.7),(2013,192.8),(2014.48,208.7)$, $(2016,212.3),(2017,221.0)))$

4. Hydrogen utilization = WITH LOOKUP (Time, $([(1995,0)-(2017,6852)],(1995,0),(1996,0)$, $(1997,0),(1998,0),(1999,0),(2000,0),(2001,0),(2002,0),(2003,0),(2004,0),(2005,0),(2006,0),(2007,0)$, $(2008,0),(2009,0),(2010,0),(2011,0),(2012,0),(2013,780.432),(2014,2265),(2015,2932),(2016,5286)$, $(2017,6852)))$

5. Recycling rate of wastewater $=$ WITH LOOKUP $($ Time, $([(1995,0)-(2017,0.98)],(1995,0.5)$, $(2002,0.81),(2006,0.9),(2007,0.91),(2017,0.98)))$

\section{References}

1. Yang, P.P.-J; Lay, O.B. Applying ecosystem concepts to the planning of industrial areas: A case study of singapore's jurong island. J. Clean. Prod. 2004, 12, 1011-1023. [CrossRef]

2. Walls, J.L.; Paquin, R.L. Organizational perspectives of industrial symbiosis. Organ. Environ. 2015, 28, 32-53. [CrossRef]

3. Martin, M.; Svensson, N.; Eklund, M. Who gets the benefits? An approach for assessing the environmental performance of industrial symbiosis. J. Clean. Prod. 2015, 98, 263-271. [CrossRef]

4. Paquin, R.L.; Busch, T.; Tilleman, S.G. Creating economic and environmental value through industrial symbiosis. Long Range Plan. 2015, 48, 95-107. [CrossRef]

5. Zhu, Q.; Côté, R.P. Integrating green supply chain management into an embryonic eco-industrial development: A case study of the guitang group. J. Clean. Prod. 2004, 12, 1025-1035. [CrossRef]

6. Liu, C.; Côté, R.P.; Zhang, K. Implementing a three-level approach in industrial symbiosis. J. Clean. Prod. 2015, 87, 318-327. [CrossRef]

7. Chertow, M.R. Industrial symbiosis: Literature and taxonomy. Ann. Rev. Energy Environ. 2000, 25, 313-337. [CrossRef]

8. Lombardi, D.R.; Laybourn, P. Redefining industrial symbiosis. J. Ind. Ecol. 2012, 16, 28-37. [CrossRef]

9. Korhonen, J.; Snäkin, J.-P. Analysing the evolution of industrial ecosystems: Concepts and application. Ecol. Econ. 2005, 52, 169-186. [CrossRef]

10. Jacobsen, N.; Anderberg, S. Understanding the evolution of industrial symbiotic networks: The case of kalundborg. In Economics of Industrial Ecology-Materials, Structural Change and Spatial Scales; MIT Press: Cambridge, MA, USA, 2005; pp. 313-336.

11. Paquin, R.L.; Howard-Grenville, J. The evolution of facilitated industrial symbiosis. J. Ind. Ecol. 2012, 16, 83-93. [CrossRef]

12. Côté, R.P.; Smolenaars, T. Supporting pillars for industrial ecosystems. J. Clean. Prod. 1997, 5, 67-74. [CrossRef] 
13. Jelinski, L.W.; Graedel, T.E.; Laudise, R.A.; McCall, D.W.; Patel, C.K. Industrial ecology: Concepts and approaches. Proc. Natl. Acad. Sci. USA 1992, 89, 793-797. [CrossRef] [PubMed]

14. Boons, F.; Spekkink, W.; Jiao, W. A process perspective on industrial symbiosis. J. Ind. Ecol. 2014, 18, 341-355. [CrossRef]

15. Boons, F.; Spekkink, W.; Mouzakitis, Y. The dynamics of industrial symbiosis: A proposal for a conceptual framework based upon a comprehensive literature review. J. Clean. Prod. 2011, 19, 905-911. [CrossRef]

16. Chertow, M.; Ehrenfeld, J. Organizing self-organizing systems. J. Ind. Ecol. 2012, 16, 13-27. [CrossRef]

17. Yu, C.; de Jong, M.; Dijkema, G.P.J. Process analysis of eco-industrial park development-The case of Tianjin, China. J. Clean. Prod. 2014, 64, 464-477. [CrossRef]

18. Spekkink, W. Institutional capacity building for industrial symbiosis in the canal zone of zeeland in the netherlands: A process analysis. J. Clean. Prod. 2013, 52, 342-355. [CrossRef]

19. Huo, C.H.; Chai, L.H. Physical principles and simulations on the structural evolution of eco-industrial systems. J. Clean. Prod. 2008, 16, 1995-2005. [CrossRef]

20. Ehrenfeld, J.; Gertler, N. Industrial ecology in practice: The evolution of interdependence at kalundborg. J. Ind. Ecol. 1997, 1, 67-79. [CrossRef]

21. Jacobsen, N.B. Industrial symbiosis in kalundborg, denmark: A quantitative assessment of economic and environmental aspects. J. Ind. Ecol. 2006, 10, 239-255. [CrossRef]

22. Park, H.S.; Rene, E.R.; Choi, S.M.; Chiu, A.S. Strategies for sustainable development of industrial park in Ulsan, south Korea-From spontaneous evolution to systematic expansion of industrial symbiosis. J. Environ. Manag. 2008, 87, 1-13. [CrossRef] [PubMed]

23. Behera, S.K.; Kim, J.-H.; Lee, S.-Y.; Suh, S.; Park, H.-S. Evolution of 'designed' industrial symbiosis networks in the ulsan eco-industrial park: 'Research and development into business' as the enabling framework. J. Clean. Prod. 2012, 29-30, 103-112. [CrossRef]

24. Barlas, Y. System Dynamics: Systemic Feedback Modeling for Policy Analysis in Knowledge For Sustainable Development_-An Insight into the Encyclopedia of Life Support Systems; UNESCO Publishing-Eolss Publishers: Paris, France; Oxford, UK, 2002.

25. Winz, I.; Brierley, G.; Trowsdale, S. The use of system dynamics simulation in water resources management. Water Resour. Manag. 2009, 23, 1301-1323. [CrossRef]

26. Doménech, T.; Davies, M. The role of embeddedness in industrial symbiosis networks: Phases in the evolution of industrial symbiosis networks. Bus. Strateg. Environ. 2011, 20, 281-296. [CrossRef]

27. Pakarinen, S.; Mattila, T.; Melanen, M.; Nissinen, A.; Sokka, L. Sustainability and industrial symbiosis-The evolution of a finnish forest industry complex. Resour. Conserv. Recycl. 2010, 54, 1393-1404. [CrossRef]

28. Costa, I.; Ferrão, P. A case study of industrial symbiosis development using a middle-out approach. J. Clean. Prod. 2010, 18, 984-992. [CrossRef]

29. Korhonen, J.; Snäkin, J.-P. Industrial ecosystem evolution of North Karelia heating energy system. Reg. Environ. Chang. 2003, 3, 128-139. [CrossRef]

30. Baldwin, J.S.; Ridgway, K.; Winder, B.; Murray, R. Modelling industrial ecosystems and the" problem" of evolution. Prog. Ind. Ecol. Int. J. 2004, 1, 39-60. [CrossRef]

31. Cao, K.; Feng, X.; Wan, H. Applying agent-based modeling to the evolution of eco-industrial systems. Ecol. Econ. 2009, 68, 2868-2876. [CrossRef]

32. Shi, L.; Chertow, M. Organizational boundary change in industrial symbiosis: Revisiting the guitang group in China. Sustainability 2017, 9, 1085.

33. Felicio, M.; Amaral, D.; Esposto, K.; Gabarrell Durany, X. Industrial symbiosis indicators to manage eco-industrial parks as dynamic systems. J. Clean. Prod. 2016, 118, 54-64. [CrossRef]

34. Ashton, W.S.; Chopra, S.S.; Kashyap, R. Life and death of industrial ecosystems. Sustainability 2017, 9, 605. [CrossRef]

35. Bain, A.; Shenoy, M.; Ashton, W.; Chertow, M. Industrial symbiosis and waste recovery in an Indian industrial area. Resour. Conserv. Recycl. 2010, 54, 1278-1287. [CrossRef]

36. Liu, C.; Zhang, K. Industrial ecology and water utilization of the marine chemical industry: A case study of Hai Hua Group (HHG), China. Resour. Conserv. Recycl. 2013, 70, 78-85. [CrossRef]

37. Yazan, D.M.; Romano, V.A.; Albino, V. The design of industrial symbiosis: An input-output approach. J. Clean. Prod. 2016, 129, 537-547. [CrossRef] 
38. Costa, I.; Massard, G.; Agarwal, A. Waste management policies for industrial symbiosis development: Case studies in European countries. J. Clean. Prod. 2010, 18, 815-822. [CrossRef]

39. Lehtoranta, S.; Nissinen, A.; Mattila, T.; Melanen, M. Industrial symbiosis and the policy instruments of sustainable consumption and production. J. Clean. Prod. 2011, 19, 1865-1875. [CrossRef]

40. Yu, F.; Han, F.; Cui, Z. Evolution of industrial symbiosis in an eco-industrial park in China. J. Clean. Prod. 2015, 87, 339-347. [CrossRef]

41. Tudor, T.; Adam, E.; Bates, M. Drivers and limitations for the successful development and functioning of EIPs (eco-industrial parks): A literature review. Ecol. Econ. 2007, 61, 199-207. [CrossRef]

42. Sterr, T.; Ott, T. The industrial region as a promising unit for eco-industrial development-Reflections, practical experience and establishment of innovative instruments to support industrial ecology. J. Clean. Prod. 2004, 12, 947-965. [CrossRef]

43. Zhu, Q.; Lowe, E.A.; Barnes, D. Industrial symbiosis in China: A case study of the guitang group. J. Ind. Ecol. 2007, 11, 31-42. [CrossRef]

44. Zhang, L.; Yuan, Z.; Bi, J.; Zhang, B.; Liu, B. Eco-industrial parks: National pilot practices in China. J. Clean. Prod. 2010, 18, 504-509. [CrossRef]

45. Fraccascia, L.; Giannoccaro, I.; Albino, V. Efficacy of Landfill Tax and Subsidy Policies for the Emergence of Industrial Symbiosis Networks: An Agent-Based Simulation Study. Sustainability 2017, 9, 521. [CrossRef]

46. Heeres, R.R.; Vermeulen, W.J.V.; de Walle, F.B. Eco-industrial park initiatives in the USA and the netherlands: First lessons. J. Clean. Prod. 2004, 12, 985-995. [CrossRef]

47. Fichtner, W.; Ingela Tietze-Stöckinger, I.; Frank, M.; Rentz, O. Barriers of interorganisational environmental management: Two case studies on industrial symbiosis. Prog. Ind. Ecol. 2005, 1, 73-88. [CrossRef]

48. Mirata, M. Experiences from early stages of a national industrial symbiosis programme in the UK: Determinants and coordination challenges. J. Clean. Prod. 2004, 12, 967-983. [CrossRef]

49. Teh, B.T.; Ho, C.S.; Matsuoka, Y.; Chau, L.W.; Gomi, K. Determinant Factors of Industrial Symbiosis: Greening Pasir Gudang Industrial Park. IOP Conf. Ser. Earth Environ. Sci. 2014, 18, 012162. [CrossRef]

50. Short, S.W.; Bocken, N.M.P.; Barlow, C.Y.; Chertow, M.R. From Refining Sugar to Growing Tomatoes. J. Ind. Ecol. 2014, 18, 603-618. [CrossRef]

51. Fraccascia, L.; Magno, M.; Albino, V. Business models for industrial symbiosis: A guide for firms. Procedia Environ. Eng. Manag. 2016, 3, 83-93.

52. Branson, R. Re-constructing kalundborg: The reality of bilateral symbiosis and other insights. J. Clean. Prod. 2016, 112, 4344-4352. [CrossRef]

53. Baas, L. Cleaner production and industrial ecosystems, a dutch experience. J. Clean. Prod. 1998, 6, $189-197$. [CrossRef]

54. Gibbs, D. Trust and networking in inter-firm relations: The case of eco-industrial development. Local Econ. 2003, 18, 222-236. [CrossRef]

55. Gibbs, D.; Deutz, P. Reflections on implementing industrial ecology through eco-industrial park development. J. Clean. Prod. 2007, 15, 1683-1695. [CrossRef]

56. Ashton, W. Understanding the organization of industrial ecosystems. J. Ind. Ecol. 2008, 12, 34-51. [CrossRef]

57. Boons, F.; Spekkink, W. Levels of institutional capacity and actor expectations about industrial symbiosis. J. Ind. Ecol. 2012, 16, 61-69. [CrossRef]

58. Boons, F.; Chertow, M.; Park, J.; Spekkink, W.; Shi, H. Industrial symbiosis dynamics and the problem of equivalence: Proposal for a comparative framework. J. Ind. Ecol. 2017, 21, 938-952. [CrossRef]

59. Beers, D.; Bossilkov, A.; Corder, G.; Berkel, R. Industrial symbiosis in the australian minerals industry: The cases of kwinana and gladstone. J. Ind. Ecol. 2007, 11, 55-72. [CrossRef]

60. Reniers, G.L.L.; Ale, B.J.M.; Dullaert, W.; Soudan, K. Designing continuous safety improvement within chemical industrial areas. Saf. Sci. 2009, 47, 578-590. [CrossRef]

61. Rodrigues, A.; Bowers, J. The role of system dynamics in project management. Int. J. Proj. Manag. 1996, 14, 213-220. [CrossRef]

62. Sterman, J.D. System dynamics modeling: Tools for learning in a complex world. Calif. Manag. Rev. 2001, 43, 8-25. [CrossRef]

63. Geng, X.; Wen, Y.; Zhou, C.; Xiao, C. Establishment of the sustainable ecosystem for the regional shipping industry based on system dynamics. Sustainability 2017, 9, 742. [CrossRef] 
64. Saysel, A.K.; Barlas, Y.; Yenigün, O. Environmental sustainability in an agricultural development project: A system dynamics approach. J. Environ. Manag. 2002, 64, 247-260. [CrossRef]

65. Vlachos, D.; Georgiadis, P.; Iakovou, E. A system dynamics model for dynamic capacity planning of remanufacturing in closed-loop supply chains. Comput. Oper. Res. 2007, 34, 367-394. [CrossRef]

66. Batten, D.F. Fostering industrial symbiosis with agent-based simulation and participatory modeling. J. Ind. Ecol. 2009, 13, 197-213. [CrossRef]

67. Liu, C.; Ma, C.; Zhang, K. Going beyond the sectoral boundary: A key stage in the development of a regional industrial ecosystem. J. Clean. Prod. 2012, 22, 42-49. [CrossRef]

68. Lu, Y.; Zhang, S.; Hao, L.; Huangfu, H.; Sheng, H. System dynamics modeling of the safety evolution of blended-wing-body subscale demonstrator flight testing. Saf. Sci. 2016, 89, 219-230. [CrossRef]

69. Rui, M.S.P.; Haie, N.; Machado, G.J. Modelling water resources using vensim PLE. In International Conference on Mathematical MODELS for Engineering Science, and Proceedings of the International Conference on Development, Energy, Environment, Economics, and Proceedings of the International Conference on Communication and Management in Technological Innovation and Academic Globalization; World Scientific and Engineering Academy and Society: Haifa, Israel, 2011; pp. 227-232.

70. Dolado, J. Qualitative simulation and system dynamics. Syst. Dyn. Rev. 1992, 8, 55-81. [CrossRef]

71. Dangelico, R.M.; Garavelli, A.C.; Petruzzelli, A.M. A system dynamics model to analyze technology districts' evolution in a knowledge-based perspective. Technovation 2010, 30, 142-153. [CrossRef]

72. Nazareth, D.L.; Choi, J. A system dynamics model for information security management. Inf. Manag. 2015, 52, 123-134. [CrossRef]

73. Sokka, L.; Lehtoranta, S.; Nissinen, A. Analyzing the environmental benefits of industrial symbiosis: Life cycle assessment applied to a Finnish forest industry complex. J. Ind. Ecol. 2010, 15, 137-155. [CrossRef]

74. Sokka, L.; Pakarinen, S.; Melanen, M. Industrial symbiosis contributing to more sustainable energy use-an example from forest industry in Kymenlaakso, Finland. J. Clean. Prod. 2011, 19, 285-293. [CrossRef]

75. Geng, Y.; Côté, R.P. Scavengers and decomposers in an eco-industrial park. Int. J. Sustain. Dev. World Ecol. 2002, 9, 333-340. [CrossRef]

76. Yung, E.H.; Chan, E.H. Implementation challenges to the adaptive reuse of heritage buildings: Towards the goals of sustainable, low carbon cities. Habitat Int. 2012, 36, 352-361. [CrossRef] 